\title{
Subsurface iron accumulation and rapid aluminum removal in the Mediterranean following African dust deposition
}

\author{
Matthieu Bressac $^{1,2}$, Thibaut Wagener ${ }^{3}$, Nathalie Leblond ${ }^{4}$, Antonio Tovar-Sánchez ${ }^{5}$, Céline Ridame ${ }^{6}$, \\ Vincent Taillandier ${ }^{1}$, Samuel Albani ${ }^{7,8}$, Sophie Guasco ${ }^{3}$, Aurélie Dufour ${ }^{3}$, Stéphanie H. M. Jacquet ${ }^{3}$, François Dulac ${ }^{8}$, \\ Karine Desboeufs $^{9}$, and Cécile Guieu ${ }^{1}$ \\ ${ }^{1}$ Sorbonne Université, CNRS, Laboratoire d'Océanographie de Villefranche, LOV, 06230 Villefranche-sur-Mer, France \\ ${ }^{2}$ Institute for Marine and Antarctic Studies, University of Tasmania, Hobart, Tasmania, Australia \\ ${ }^{3}$ Aix Marseille Univ., CNRS, IRD, Université de Toulon, MIO UMR 110, 13288 Marseille, France \\ ${ }^{4}$ Sorbonne Université, CNRS, Institut de la Mer de Villefranche, IMEV, 06230 Villefranche-sur-Mer, France \\ ${ }^{5}$ Department of Ecology and Coastal Management, Institute of Marine Sciences of Andalusia (ICMAN-CSIC), \\ 07190 Puerto Real, Spain \\ ${ }^{6}$ Sorbonne Université, LOCEAN, 4 Place Jussieu - 75252 Paris Cedex 05, France \\ ${ }^{7}$ Department of Environmental and Earth Sciences, University of Milano-Bicocca, Milan, Italy \\ ${ }^{8}$ Laboratoire des Sciences du Climat et de l'Environnement (LSCE), UMR 8212 CEA-CNRS-UVSQ, \\ Institut Pierre-Simon Laplace, Université Paris-Saclay, 91191 Gif-sur-Yvette, France \\ ${ }^{9}$ Laboratoire Interuniversitaire des Systèmes Atmosphériques (LISA), UMR7583 CNRS, Université de Paris, \\ Université Paris-Est Créteil, Institut Pierre-Simon Laplace, 75013 Paris, France
}

Correspondence: Matthieu Bressac (matthieu.bressac@imev-mer.fr)

Received: 2 April 2021 - Discussion started: 13 April 2021

Revised: 3 November 2021 - Accepted: 18 November 2021 - Published: 15 December 2021

\begin{abstract}
Mineral dust deposition is an important supply mechanism for trace elements in the low-latitude ocean. Our understanding of the controls of such inputs has been mostly built on laboratory and surface ocean studies. The lack of direct observations and the tendency to focus on near-surface waters prevent a comprehensive evaluation of the role of dust in oceanic biogeochemical cycles. In the frame of the PEACETIME project (ProcEss studies at the Air-sEa Interface after dust deposition in the MEditerranean sea), the responses of the aluminum ( $\mathrm{Al})$ and iron $(\mathrm{Fe})$ cycles to two dust wet deposition events over the central and western Mediterranean Sea were investigated at a timescale of hours to days using a comprehensive dataset gathering dissolved and suspended particulate concentrations, along with sinking fluxes.

Dissolved $\mathrm{Al}(\mathrm{dAl})$ removal was dominant over $\mathrm{dAl}$ released from dust. The Fe/Al ratio of suspended and sinking particles revealed that biogenic particles, and in particular diatoms, were key in accumulating and exporting Al relative to Fe. By combining these observations with published $\mathrm{Al} / \mathrm{Si}$ ratios of diatoms, we show that adsorption onto bio-
\end{abstract}

genic particles, rather than active uptake, represents the main sink for dAl in Mediterranean waters. In contrast, systematic dissolved $\mathrm{Fe}(\mathrm{dFe})$ accumulation occurred in subsurface waters $(\sim 100-1000 \mathrm{~m})$, while $\mathrm{dFe}$ input from dust was only transient in the surface mixed layer. The rapid transfer of dust to depth, the Fe-binding ligand pool in excess to dFe in subsurface (while nearly saturated in surface), and low scavenging rates in this particle-poor depth horizon are all important drivers of this subsurface $\mathrm{dFe}$ enrichment.

At the annual scale, this previously overlooked mechanism may represent an additional pathway of dFe supply for the surface ocean through diapycnal diffusion and vertical mixing. However, low subsurface $\mathrm{dFe}$ concentrations observed at the basin scale $\left(<0.5 \mathrm{nmol} \mathrm{kg}^{-1}\right)$ cause us to question the residence time for this dust-derived subsurface reservoir and hence its role as a supply mechanism for the surface ocean, stressing the need for further studies. Finally, these contrasting responses indicate that $\mathrm{dAl}$ is a poor tracer of $\mathrm{dFe}$ input in the Mediterranean Sea. 


\section{Introduction}

Globally, iron (Fe) supply to the surface ocean sets the productivity of major phytoplankton groups (Moore et al., 2013). Among the multiple sources of Fe, atmospheric deposition of mineral dust represents an important supply mechanism in the low-latitude ocean (Duce et al., 1991; Jickells et al., 2005; Conway and John, 2014) and plays a key role in the functioning of low- nutrient, low-chlorophyll (LNLC) systems (e.g., Guieu et al., 2014a). Despite widespread attention over the last 3 decades, large uncertainties remain in the factors controlling aerosol Fe solubility (Meskhidze et al., 2019). Consequently, poorly constrained controls of Fe solubility partly explain the substantial inter-model difference in the atmospheric dFe input flux to the global ocean ( 1-30 $\mathrm{Gmol} \mathrm{yr}^{-1}$; Tagliabue et al., 2016) and hinder accurate predictions of the impact of dust on ocean productivity.

African dust deposition events have long been known to impact trace element concentrations and fluxes in the upper water column of the Mediterranean (e.g., Buat-Ménard et al., 1989; Davies and Buat-Ménard, 1990; Quétel et al., 1993; Guerzoni et al., 1999; Heimbürger et al., 2011). Our understanding of the role of dust in marine biogeochemical cycles remains limited, however, partly resulting from the difficulty in quantifying atmospheric dust fluxes to the surface ocean at short timescales. In the absence of direct assessments of atmospheric inputs, marine concentrations of tracers such as aluminum ( $\mathrm{Al}$ ) have been widely used to constrain these fluxes (e.g., Measures and Brown, 1996; Han et al., 2008; Anderson et al., 2016; Menzel Barraqueta et al., 2019). Al is predominantly of crustal origin and is characterized by a similar fractional solubility to $\mathrm{Fe}$ with a longer residence time in seawater. Al could thus be used to constrain the integrated input of dust $\mathrm{Fe}$ over seasonal timescales (Dammshäuser et al., 2011). However, the fact that the distribution of Al can itself be controlled by biological activity (e.g., Mackenzie et al., 1978; Moran and Moore, 1988a; Li et al., 2013; Middag et al., 2015; Rolison et al., 2015) causes us to question its quality as a tracer.

In addition, since dust deposition is highly episodic in time and spatially patchy (Donaghay et al., 1991; Guieu et al., 2014a; Vincent et al., 2016), direct observations at sea are extremely challenging and hence sparse (e.g., Croot et al., 2004; Rijkenberg et al., 2008). To overcome this limitation, a variety of small-volume enclosed systems have been used to quantify Fe solubility from dust. Although yielding important insights into atmospheric trace element solubilities (Baker and Croot, 2010, and references therein), these systems do not fully simulate in situ conditions (de Leeuw et al., 2014), motivating the development of larger volume experiments $(>100 \mathrm{~L})$, where dust particles are free to sink and interact with dissolved and particulate organic matter while sinking (Bressac and Guieu, 2013; Guieu et al., 2014b; Herut et al., 2016; Gazeau et al., 2021). Two key findings emerged from these large-volume experiments. First, they demonstrated the pivotal role played by the in situ biogeochemical conditions at the time of deposition in controlling post-depositional processes (i.e., dissolution, organic complexation, adsorption, colloidal aggregation) and their interplay (Wagener et al., 2010; Bressac and Guieu, 2013; Wuttig et al., 2013). The most striking and unexpected consequence is that upon deposition, dust can act as a net sink of $\mathrm{dFe}$ through scavenging (Wagener et al., 2010; Ye et al., 2011). Second, the large range in $\mathrm{Fe}$ solubility observed in seawater depending on the season reveals that oceanic rather than atmospheric conditions determine the flux of "truly" bioavailable Fe to the surface ocean (Bressac and Guieu, 2013). However, these findings are only valid in the first meters of the water column, and direct observations of the whole water column are needed if we are to fully understand the role of dust in the oceanic iron cycle.

For this purpose, the Mediterranean Sea is a particularly relevant region. This semi-enclosed basin, characterized by a west-to-east gradient in oligotrophy, receives some of the largest dust inputs of the ocean (Guerzoni et al., 1999), mostly in the form of wet deposition in the central and western part of the basin, and a few intense events may account for the bulk of the annual deposition (Loÿe-Pilot and Martin, 1996; Vincent et al., 2016). The PEACETIME project (ProcEss studies at the Air-sEa Interface after dust deposition in the MEditerranean sea) and oceanographic campaign on board the R/V Pourquoi Pas? provided a unique opportunity to directly observe the biogeochemical effects of two mineral dust wet deposition events of contrasting intensity that occurred during late spring 2017 in the central and western open Mediterranean Sea (Guieu et al., 2020). The presence of the $\mathrm{R} / \mathrm{V}$ before, during, and/or a few days after deposition allowed us to investigate (1) the parameters and processes shaping the contrasting distributions of $\mathrm{dAl}$ and $\mathrm{dFe}$, (2) the importance of the timescale considered when assessing the flux of bioavailable Fe to the surface ocean, and (3) the relevance of using $\mathrm{dAl}$ to constrain $\mathrm{dFe}$ input from dust.

\section{Materials and methods}

\subsection{Oceanographic cruise}

The

PEACETIME

cruise (https://doi.org/10.17600/15000900) was conducted during late spring conditions in May and June 2017 aboard the R/V Pourquoi Pas? in the central and western Mediterranean Sea. In total, 10 short stations $(\sim 8 \mathrm{~h})$ and 3 long stations located in the Tyrrhenian Sea (TYR; occupation $=4 \mathrm{~d}$ ), the Ionian Sea (ION; 4d), and in the western Algerian basin (FAST; $5 \mathrm{~d}$ ) were occupied (Fig. 1). FAST was an opportunistic station dedicated to investigating the biogeochemical effects of a dust deposition event by combining atmospheric and oceanographic in situ measurements before, during, and after deposition (Guieu et al., 2020). At all stations, a 


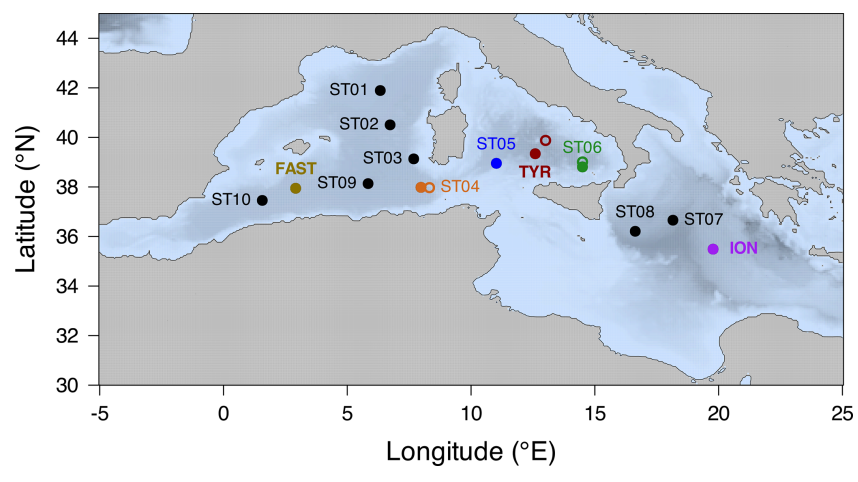

Figure 1. Sampling locations during the PEACETIME cruise (filled circles). The cruise track consisted of 10 short stations and 3 long stations (TYR, ION, and FAST). Open circles correspond to the stations 64PE370_12 (orange), 64PE374_13 (red), and 64PE374_12 (green) from the GEOTRACES GA04 section (Rolison et al., 2015; Gerringa et al., 2017) used for comparison in Fig. 3. Note that the same color code is used in Figs. 3, 6, and 7.

standard CTD rosette with 24 Niskin bottles (12 L) equipped with a Sea-Bird SBE9 CTD, transmissometer, chlorophyll fluorescence (Chelsea Acquatracka), photosynthetically active radiation and oxygen (SBE43) sensors, and a trace metal clean (TMC) titanium rosette were deployed to sample the water column for biological and chemical parameters. Samples for aluminum and iron analyses were collected using the TMC titanium rosette mounted with GO-FLO bottles deployed on a Kevlar cable with a dedicated clean winch, while samples for particulate $\mathrm{Al}(\mathrm{pAl})$ determination were also collected at all the stations from the standard rosette (see Sect. 2.3 and Supplement Table S1).

\subsection{Dissolved $\mathrm{Al}$ and Fe concentrations}

Immediately after recovery, the GO-FLO bottles were transferred inside a class-100 clean laboratory container. Seawater samples were directly filtered from the GO-FLO bottles through acid-cleaned $0.2 \mu \mathrm{m}$ capsule filters (Sartorius Sartobran P capsule $0.45 / 0.2 \mu \mathrm{m}$ ). Dissolved Fe and Al samples were stored in acid-washed low-density polyethylene bottles and immediately acidified to $\mathrm{pH} 1.8$ (quartz-distilled $\mathrm{HCl}$ ) under a laminar flow hood.

Dissolved Al analyses were conducted on board using the fluorometric method described by Hydes and Liss (1976). Briefly, the samples were buffered to $\mathrm{pH} 5$ with ammonium acetate, and the reagent lumogallion was added. The samples were then heated to $80^{\circ} \mathrm{C}$ for $1.5 \mathrm{~h}$ to accelerate the complex formation. The fluorescence of the sample was measured with a Jasco FP-2020 Plus spectrofluorometer (excitation wavelength $495 \mathrm{~nm}$, emission wavelength $565 \mathrm{~nm}$ ). Calibration was realized with additions of Al standard solution in seawater. The detection limit (DL; 3 times the standard deviation (SD) of the concentrations measured from the dAl-poor seawater used for calibration) varied between
0.2 and $0.5 \mathrm{nmol} \mathrm{kg}^{-1}$. The reagent blank determined by measuring acidified ultrapure water varied between 0.9 and $1.7 \mathrm{nmol} \mathrm{kg}^{-1}$.

Dissolved Fe concentrations were measured (mostly on board in the class-100 clean laboratory) using an automated flow injection analysis (FIA) with online preconcentration and chemiluminescence detection (Bonnet and Guieu, 2006). The stability of the analysis was assessed by analyzing an internal acidified seawater standard daily. On average, the DL was $15 \mathrm{pmol} \mathrm{kg}^{-1}$ (3 times the SD of the concentration measured five times from the same dFe-poor seawater), and the accuracy of the method was controlled by analyzing the GEOTRACES seawater standards SAFe D1 $\left(0.64 \pm 0.13 \mathrm{nmol} \mathrm{kg}^{-1}(n=19)\right.$, consensus value $\left.0.67 \pm 0.04 \mathrm{nmol} \mathrm{kg}^{-1}\right), \mathrm{GD}\left(1.04 \pm 0.10 \mathrm{nmol} \mathrm{kg}^{-1}\right.$ $(n=10)$, consensus value $\left.1.00 \pm 0.10 \mathrm{nmol} \mathrm{kg}^{-1}\right)$, and GSC $\left(1.37 \pm 0.16 \mathrm{nmol} \mathrm{kg}^{-1} \quad(n=4)\right.$, consensus value $1.50 \pm$ $0.11 \mathrm{nmol} \mathrm{kg}^{-1}$ ) on a regular basis.

\subsection{Suspended particulate trace metals}

Just prior to sampling for particulate trace metals (pTMs), GO-FLO bottles were gently mixed, and pTMs were sampled directly online from the pressurized $(0.2 \mu \mathrm{m}$ filtered $\mathrm{N}_{2}$ ) GO-FLO bottles onto acid-cleaned $25 \mathrm{~mm}$ diameter $\mathrm{Su}-$ por $0.45 \mu \mathrm{m}$ polyethersulfone filters mounted on Swinnex polypropylene filter holders (Millipore), following GEOTRACES recommendations. Filtration was stopped when the filter clogged or the bottle was empty. On average, each particulate concentration was obtained by filtering $4.8 \mathrm{~L}$ (range $1.1-10.2 \mathrm{~L}$ ). When the filtration was complete, filter holders were transferred under a laminar flow hood, and residual seawater was removed using a polypropylene syringe. Filters were stored in acid-cleaned petri slides, left open under the laminar flow hood for $\sim 24 \mathrm{~h}$ to allow the filters to dry. Particulate samples were digested $(10 \% \mathrm{HF} / 50 \%$ $\mathrm{HNO}_{3}(v / v)$ ) following the protocol described in the GEOTRACES “Cookbook" (Cutter et al., 2010) and Planquette and Sherrell (2012). Procedural blanks consisted of unused acid-cleaned filters. Analyses were performed on a HR-ICPMS (high-resolution inductively coupled plasma mass spectrometer; Element XR, Thermo-Fisher Scientific). The accuracy of the measurements was established using the certified reference materials (CRMs) MESS-4 and PACS-3 (marine sediments, National Research Council Canada) (Supplement Table S2).

In addition, pAl concentrations were also obtained at all the stations from the standard rosette (Supplement Table $\mathrm{S} 1$ ). This additional pAl dataset already published by Jacquet et al. (2021) was obtained according to the sampling, processing, and analysis methods described in Jacquet al. (2015). Briefly, 4 to $6 \mathrm{~L}$ of seawater collected with the Niskin bottles was filtered onto acid-cleaned $47 \mathrm{~mm}$ polycarbonate filters $(0.4 \mu \mathrm{m}$ porosity). Filters were rinsed with Milli-Q grade water and dried at $50^{\circ} \mathrm{C}$. A total digestion 
of the membranes was performed using a tri-acid mixture $\left(0.5 \mathrm{~mL} \mathrm{HF} / 1.5 \mathrm{~mL} \mathrm{HNO}_{3} / 1 \mathrm{~mL} \mathrm{HCl}\right)$, and analyses were performed on the same HR-ICP-MS. A good agreement was obtained when comparing pAl concentrations obtained with the TMC and standard rosettes at ION and FAST (difference in sampling time at TYR prevents quantitative comparison; see Sect. 4.1) (Supplement Fig. S1), demonstrating the absence of contamination for $\mathrm{pAl}$ when using the standard rosette.

\subsection{Export fluxes and composition}

Sinking particles were collected at $\sim 200,500$, and $1000 \mathrm{~m}$ depth using PPS5 sediment traps (Technicap, France; $1 \mathrm{~m}^{2}$ collection area) deployed on a free-drifting mooring for 4 (TYR and ION) and $5 \mathrm{~d}$ (FAST). Cups were filled with filtered seawater and buffered formaldehyde ( $2 \%$ final concentration) as a biocide. Once recovered, each cup representing $24 \mathrm{~h}$ of collection was stored in the dark at $4{ }^{\circ} \mathrm{C}$ until processed. Samples were treated following the standard protocol followed at the "Cellule Pièges", a national service of the French INSU-CNRS (Guieu et al., 2005), following the JGOFS' protocol. After removing the swimmers, the remaining sample was rinsed three times with ultrapure water in order to remove salt and then freeze-dried. The total amount of material collected was weighed to quantify the total exported flux. Several aliquots were then used to measure the following components: total and organic carbon, particulate $\mathrm{Al}$ and $\mathrm{Fe}$, and lithogenic and biogenic silica (LSi and $\mathrm{BSi}$, respectively). Total carbon, particulate organic carbon (POC) (after removing inorganic carbon by acidification with $\mathrm{HCl} 2 \mathrm{~N}$ ), and particulate organic nitrogen (PON) were measured on a CHN elemental analyzer (2400 Series II CHNS/O Elemental Analyzer, Perkin Elmer). For one sample (TYR 1000 m), five aliquots were analyzed, yielding a coefficient of variation (CV) of $6 \%$. Particulate inorganic carbon (PIC) was quantified by subtracting POC from total particulate carbon. Particulate $\mathrm{Fe}$ and $\mathrm{Al}$ concentrations were determined by an ICP-AES (inductively coupled plasma atomic emission spectrometer, Spectro ARCOS Ametek) after acid digestion following the protocol described in Ternon et al. (2010). Blanks were negligible ( $<0.8 \%$ of the lowest $\mathrm{Al}$ and $\mathrm{Fe}$ concentrations of the digested aliquots), and the efficiency of the acid digestion was established using the CRM GBW-07313 (marine sediment, National Research Center for CRMs, China) (Supplement Table S2). Samples for BSi and LSi (two or three aliquots) were digested ( $\mathrm{NaOH}$ at $95^{\circ} \mathrm{C}$ and $\mathrm{HF}$ at ambient temperature, respectively) and concentrations analyzed by colorimetry (Analytikjena Specor 250 Plus spectrophotometer) (Nelson et al. 1989; Mullin and Riley, 1955). Mean export fluxes and composition of exported material are presented in Table 1.

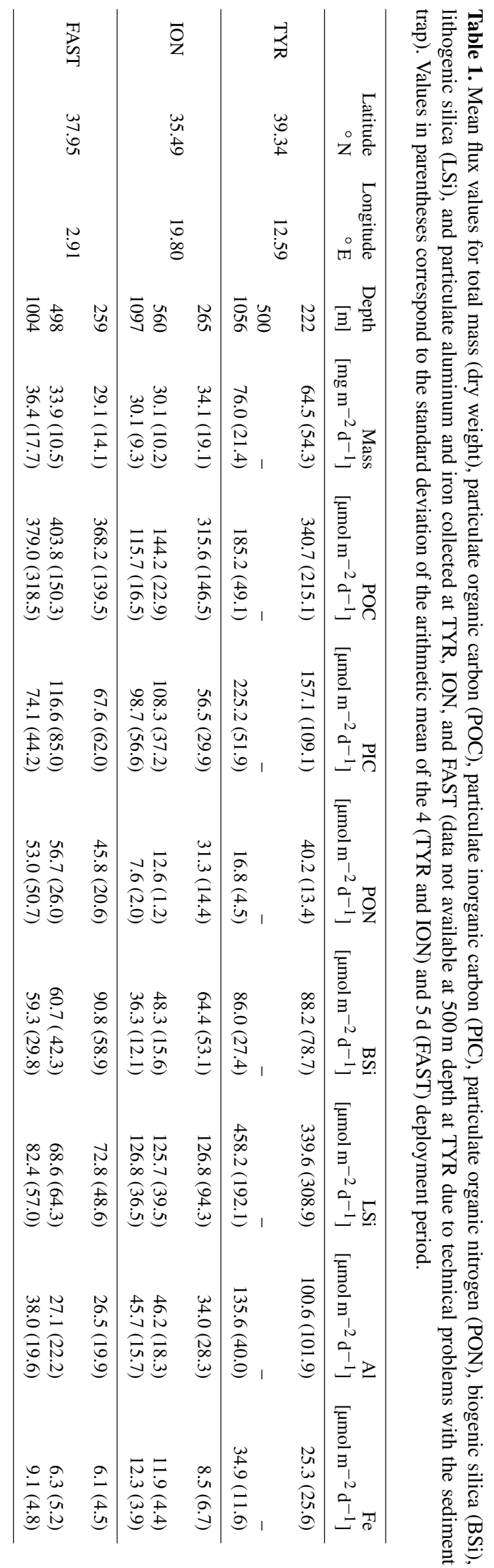

https://doi.org/10.5194/bg-18-6435-2021 


\subsection{Inventories and Kd}

Discrete measurements at different depths were used to calculate the water-column integrated $\mathrm{Al}$ and $\mathrm{Fe}$ inventories $\left(\mu \mathrm{mol} \mathrm{m}{ }^{-2}\right)$ by trapezoidal integration. The concentration measured nearest to the surface was assumed to be constant up to $0 \mathrm{~m}$. At FAST, six replicate measurements of $\mathrm{dAl}$ and $\mathrm{dFe}$ were performed at 5 and $400 \mathrm{~m}$ depth from two sets of six GO-FLO bottles. The CVs obtained at 5 and $400 \mathrm{~m}$ depths were used to determine the uncertainties in the 0-20 and 0$200 \mathrm{~m}$ inventories, respectively. Variability among replicates was higher for $\mathrm{dFe}(\mathrm{CV}=11.3 \%$ and $6.9 \%$ at 5 and $400 \mathrm{~m}$ depth, respectively) than for $\mathrm{dAl}(\mathrm{CV}=5.3 \%$ and $1.1 \%$ at 5 and $400 \mathrm{~m}$ depth, respectively), potentially reflecting a smallscale variability in the dFe distribution.

At the FAST station, the partitioning coefficient between the particulate and dissolved phases (Kd; [particulate] / [dissolved]) was used to investigate exchanges between dissolved and particulate pools of $\mathrm{Al}$ and $\mathrm{Fe}$. Following the relative change over time of this metric allowed potential artifacts related to change in water masses driven by lateral advection to be excluded (Guieu et al., 2020).

\section{Results}

\subsection{Biogeochemical conditions}

The PEACETIME cruise took place in late spring when the stratification of the upper water column was well established with the mixed layer depth ranging between $\sim 10$ and $20 \mathrm{~m}$ along the cruise track (Van Wambeke et al., 2020). Surface chlorophyll $a$ concentrations $\left(<0.1 \mu \mathrm{g} \mathrm{L}^{-1}\right)$ were typical of oligotrophic conditions (Guieu et al., 2020). A diatomdominated deep chlorophyll maximum (DCM) that coincided with a maximum in biomass and primary production was well developed and observed all along the cruise track (Marañón et al., 2021). POC downward fluxes measured at $200 \mathrm{~m}$ depth were similar at the three long stations, while downward fluxes of $\mathrm{Al}$ and $\mathrm{LSi}$, two proxies for dust, were maximum at TYR (Table 1). At the surface, dAl distribution was characterized by a marked west-to-east increasing gradient (Supplement Fig. S2b), driven by advective mixing between (dAl poor) Atlantic and Mediterranean waters and by the accumulation of dust and reflected by a strong relationship between surface dAl concentrations and salinity (Guerzoni et al., 1999; Rolison et al., 2015). All along the transect, $\mathrm{dFe}$ concentrations were high in the upper $100 \mathrm{~m}$ (up to $2.7 \mathrm{nmol} \mathrm{kg}^{-1}$ ) and decreased to levels $<0.5 \mathrm{nmol} \mathrm{kg}-1$ below the euphotic layer (Supplement Fig. S2c). Subsurface patches of high $\mathrm{dFe}$ concentrations previously observed in the eastern Mediterranean basin, and attributed to hydrothermal activity and mud-volcanoes (Gerringa et al., 2017), were not observed along our cruise track.

\subsection{Dust deposition over the central and western Mediterranean Sea}

The impact in the water column of two dust deposition events of contrasting magnitudes was studied during the cruise. They occurred in the area of the TYR and FAST stations (Fig. 1), on 11-12 May and 3-5 June, respectively. The first deposition event in the southern Tyrrhenian Sea was not directly observed but hypothesized based on satellite observations of intense dust plume transport and water-column $\mathrm{Al}$ inventory presented in the following. The combined analysis of time series of quick-looks of operational aerosol products from MSG/SEVIRI (Fig. 2a) and from meteorological and dust transport models available during the campaign (Guieu et al., 2020; Supplement Fig. S3) allowed us to suspect that a red rain event likely occurred over the southern Tyrrhenian Sea on 11 May and possibly early on 12 May. The daytime daily mean aerosol optical depth (AOD) product over oceanic areas (Thieuleux et al., 2005) shows that a large dust plume was exported from the Tunisian and Libyan coasts towards southern Italy and Greece from 10 May (Fig. 2a). Up to $1.5-1.6$ AOD at $550 \mathrm{~nm}\left(\mathrm{AOD}_{550}\right)$ (i.e., about $2 \mathrm{~g} \mathrm{~m}^{-2}$ of dust in the column assuming a specific extinction cross-section of dust of $0.77 \mathrm{~m}^{2} \mathrm{~g}^{-1}$ following Dulac et al., 1992) was observed on 12 May north of Sicily in the area of the Tyrrhenian stations, a rather high value relatively unusual in this area (Gkikas et al., 2016). On 11 May, clouds developed over most of the area affected by dust, whereas clear (turbid) sky was again present during daytime on 12 May. The extension and dynamics of this dust transport event were reasonably well forecasted by the various existing regional dust transport models available during the campaign (Supplement Fig. S3), including the set of models of the World Meteorological Organization Sand and Dust Storm Warning Advisory and Assessment System operated by the Barcelona Supercomputing Center (BSC; Huneeus et al., 2016), the SKIRON/Dust model operated by the Atmospheric Modeling and Weather Forecasting Group of the National University of Athens (Spyrou et al., 2010), the CAMS model operated by the European Centre for Medium-Range Weather Forecasts (ECMWF; Flemming et al., 2015), the NCEP/GFS model operated by the U.S. National Weather Service (Han et al., 2017), the NAAPS model modified from that of Christensen (1997) and operated by the U.S. Naval Research Laboratory, and the TAU/DREAM8 model operated by the Weather Research Centre of the Tel Aviv University (TAU; Kishcha et al., 2008). The dust plume extension in the cloudy area on 11 May is illustrated by Supplement Fig. S3a and b. Most meteorological models predicted significant precipitation over the Tyrrhenian Sea on 11 May (Supplement Fig. S3c). Dust transport models producing dust deposition fluxes generally forecasted dust wet deposition on 11 May between Tunisia and Italy but with significant variability on the location, extent, and schedule. The NMMB/BSC and SKIRON models predicted a significant 
wet deposition flux of dust, with at least $1.5 \mathrm{~g} \mathrm{~m}^{-2}$ over $6 \mathrm{~h}$ in the area of our stations ST05, TYR, and ST06 in the afternoon of 11 May (Supplement Fig. S3d and e). The DREAM model versions operated by the BSC and TAU, however, forecasted much lower values or even no dust wet deposition in the Tyrrhenian stations area (Supplement Fig. S3f). However, model reanalyses now available do not show any precipitation in the area between 10 and 13 May (Fig. 2b). However, the half-hourly, $0.1^{\circ}$ resolution Global Precipitation Measurement (GPM) mission Integrated Multi-satellitE Retrievals for GPM (IMERG) final run images of the rainfall rate (GPM_3IMERGHH_v06 product; Huffman et al., 2015) report the occurrence of light rains in the Tyrrhenian Sea in the early morning of 11 May, especially around $12^{\circ} \mathrm{E}$ and between 39 and $40^{\circ} \mathrm{N}(<1 \mathrm{~mm}$ of accumulated precipitation, with a large error of up to several millimeters; Fig. 2b). The study of the TRMM-3B42-v6 product, a former multi-satellite, 3-hourly precipitation product in the western Mediterranean region has shown that the detection of light rainfall is difficult when compared to rain gauge observations, with many occurrences missed by the satellite product (Sarrand et al., 2012). Indeed, the minimum corresponding random error image is $0.238 \mathrm{~mm} \mathrm{~h}^{-1}$ for pixels without detected rain, which can be assimilated to a lower detection limit. During the whole day, some light rain cells remain visible near Sardinia, Sicily, or southern Italy. It is therefore well possible that a much larger area of the Tyrrhenian Sea than that reported by the GPM IMERG images was affected by light precipitation on that day. For simplicity, 11 May 2017, at 18:00 UTC, will be considered as the time of deposition, that is approximately 3 to $10 \mathrm{~d}$ before our sampling of the area.

During the early June deposition event in the western Algerian basin, precipitation was directly observed in the area of the R/V and even sampled on board (Desboeufs et al., 2021), associated with a dust transport event of moderate extent and intensity over the southwestern Mediterranean basin. The $\mathrm{AOD}_{550}$ peaked at about 0.40 in the area of the FAST station (Desboeufs et al., 2021), corresponding to a maximum columnar dust load $<0.4 \mathrm{~g} \mathrm{~m}^{-2}$, assuming a non-dust background $\mathrm{AOD}_{550}$ in the boundary layer of $0.10-0.15$, as observed north of the plume or the day before the plume arrived. This dust plume encountered a massive rain front covering $\sim 80000 \mathrm{~km}^{2}$ and moving eastward from Spain and North Africa regions (Desboeufs et al., 2021). Direct atmospheric and oceanographic observations of this event were possible thanks to a dedicated "fast action" strategy (see Guieu et al., 2020, for details). Two rain periods concomitant with the dust plume transported in altitude (1 to $4 \mathrm{~km}$ ) allowed below-cloud deposition of dust in the FAST station area, as confirmed by onboard lidar records (Desboeufs et al., 2021). The first rain period occurred on 3 June in the neighboring area of the $\mathrm{R} / \mathrm{V}$, and the second one occurred from 4 (22:00 UTC) to 5 June (09:00 UTC) and was sampled on board the R/V on 5 June from 00:36 to 01:04 UTC (Des- boeufs et al., 2021). This second rain event was characterized by a dust signature clearly revealed by the chemical composition of the rain. From the total (dissolved + particulate) $\mathrm{Al}$ concentration measured in this rainwater sample, a dust flux of $65 \pm 18 \mathrm{mg} \mathrm{m}^{-2}$ was derived (Desboeufs et al., 2021). This sampled flux, considered as relatively modest compared to the multi-year record in this area (Vincent et al., 2016), was likely in the lower range of the total dust deposition flux that affected the whole area between 3 and 5 June.

\subsection{Reconstruction of the dust deposition fluxes}

The absence of direct measurement of the dust deposition flux over the Tyrrhenian Sea and the limited spatial coverage of collection of atmospheric dust and rain at the FAST station call for an alternative approach to estimate dust deposition fluxes. For this purpose, we used the water-column $\mathrm{Al}$ inventory. We acknowledge that this approach involves uncertainties, as do all the observational approaches employed so far to quantify deposition (Anderson et al., 2016). Caveats include (1) other sources of pAl and (2) some uncertainties into the derived dust fluxes that could come from the sampling method (Twining et al., 2015a), the time lag between deposition and sampling favoring dispersion of dust by lateral mixing, and, to a lesser extent, the limited vertical resolution below $500 \mathrm{~m}$ depth (Fig. 3a-d).

\subsubsection{Central Mediterranean Sea}

Dust deposition flux over the Tyrrhenian Sea was estimated from the $\mathrm{Al}_{\text {excess }}$ inventories corresponding to the difference between the measured $0-1000 \mathrm{~m} \mathrm{pAl}$ inventories and a background $0-1000 \mathrm{~m} \mathrm{pAl}$ inventory. In the absence of pre-depositional observations and historic $\mathrm{pAl}$ data (to the best of our knowledge), the median pAl vertical profile obtained during the cruise at the other stations not impacted by this event (bold grey line on Fig. 3a-d), similar or slightly higher than pAl data available for the open Mediterranean Sea (e.g., Sarthou and Jeandel, 2001), was used as a background level. The comparison between the measured $\mathrm{pAl}$ vertical profiles and this background level revealed a marked excess in pAl south of Sardinia (ST04) and in the southern Tyrrhenian (ST05, TYR, and ST06; Fig. 3a-d and Table 2). This spatial extent is in good agreement with the maps of precipitation and dust wet deposition provided for 11 May by the ARPEGE, SKIRON, and NMMB/BSC models (Supplement Fig. S3). The obtained $\mathrm{Al}_{\text {excess }}$ inventories were further corrected for the loss of $\mathrm{pAl}$ associated with the sinking flux using the pAl downward flux measured at $1000 \mathrm{~m}$ depth at the TYR station (assuming a constant flux over the 3 to $10 \mathrm{~d}$ period after deposition). Assuming that $\mathrm{Al}$ represents $7.1 \%$ of the dust in mass (Guieu et al., 2002), and further assuming that $\mathrm{Al}_{\text {excess }}$ resulted from a single dust event, a dust deposition flux ranging between 1.7 (ST06) and $9.2 \mathrm{~g} \mathrm{~m}^{-2}$ (ST04) was derived from these $\mathrm{Al}_{\text {excess }}$ inventories (Table 2). Large 
(a) MSG/SEVIRI $\mathrm{AOD}_{550}$

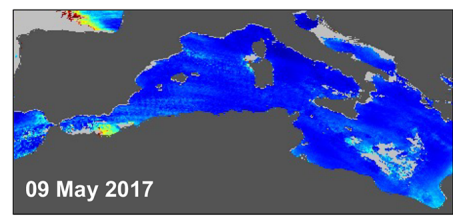

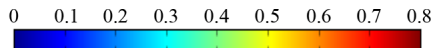
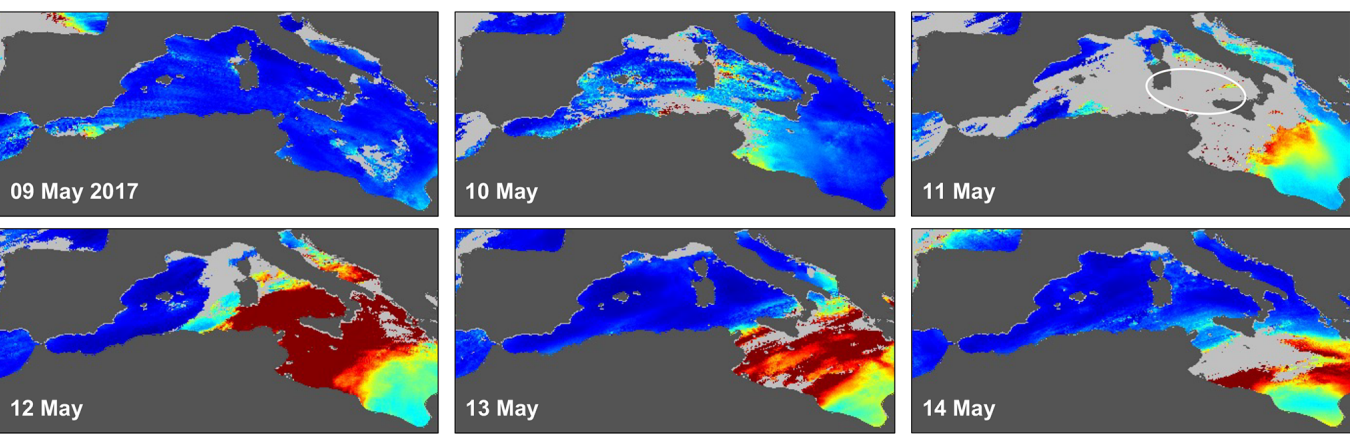

(b) GPMM precipitation on 11 May 2017 (4:00-5:30 UTC), and standard error $\left(\mathrm{mm} \mathrm{hr}^{-1}\right)$
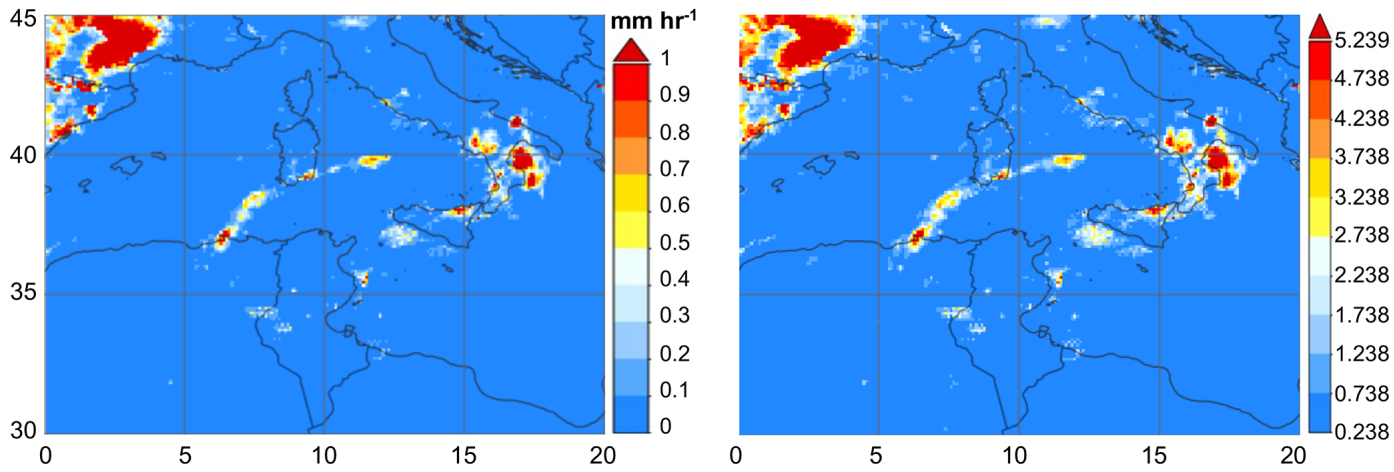

Figure 2. (a) MSG/SEVIRI-derived daily (daytime) mean aerosol optical depth; the white ellipse on 11 May image includes the location of the five Tyrrhenian stations reported in Fig. 1; (b) Left: time-averaged map of the GPM mission multi-satellite precipitation final run estimate with gauge calibration $\left(\mathrm{mm} \mathrm{h}^{-1}\right)$ over 04:00-05:30 UTC on 11 May 2017 in the western Mediterranean region, from the half-hourly, 0.1 ${ }^{\circ}$ resolution GPM_3IMERGHH v06 product (Huffmann et al., 2015). Right: corresponding random error (mm $\mathrm{h}^{-1}$ ). After images produced by the Giovanni online data system (Acker and Lepkouth, 2007).

uncertainties are associated with these dust flux estimates, partly due to potential additional sources of pAl that are suspected for fluxes derived from ST04 and ST05 but unlikely for TYR and ST06 (see Sect. 4.1). Nevertheless, the approach remains valuable to estimate the magnitude of this dust event.

This range of dust deposition flux is of similar magnitude to the annual flux observed during former periods in the west central (7.4 $\mathrm{g} \mathrm{m}^{-2} \mathrm{yr}^{-1}$; Vincent et al., 2016) and northwestern Mediterranean Sea $\left(11.4 \mathrm{~g} \mathrm{~m}^{-2} \mathrm{yr}^{-1}\right.$; Ternon et al., 2010), highlighting the remarkable magnitude of this event. Furthermore, this comparison with annual fluxes confirms that the annual deposition of African dust in the Mediterranean region is generally driven by only a few intense events (Loÿe-Pilot and Martin, 1996; Guerzoni et al., 1999; Kubilay et al., 2000; Desboeufs et al., 2018). The strong spatial variability of these dust flux estimates, with a marked west-toeast gradient, might result from the varying time lag between deposition and sampling of the water column at these different stations (Table 2) but also from the patchiness of the rainfalls associated with the rain front (Supplement Fig. S3). Indeed, Vincent et al. (2016) showed that high-deposition events in the western Mediterranean are often limited spatially, although the associated dust plumes may affect a large part of the basin. By assuming that the deposition was spatially homogeneous over the southern Tyrrhenian, an Al export flux of more than $4000 \mu \mathrm{mol} \mathrm{m}{ }^{-2} \mathrm{~d}^{-1}$ is needed to explain the difference in the $\mathrm{Al}_{\text {excess }}$ inventory observed between ST04, ST05, and TYR (i.e., $~ 3.6$ to $8.4 \mathrm{~d}$ after deposition). This is an order-of-magnitude difference compared to the $\mathrm{Al}$ export flux measured at TYR $\sim 5$ to $8 \mathrm{~d}$ after deposition (136 $\pm 40 \mu \mathrm{mol} \mathrm{m}^{-2} \mathrm{~d}^{-1}$; Table 1), indicating that the observed spatial variability was primarily driven by the precipitation patchiness rather than related to the time lag between deposition and observations.

\subsubsection{Western Mediterranean Sea}

At the FAST station, dissolved and particulate $\mathrm{Al}$ and $\mathrm{Fe}$ concentrations were measured at high temporal and vertical resolutions before, during, and after the wet deposition of dust (Supplement Fig. S4). About $6 \mathrm{~h}$ after deposition, the total (dissolved + particulate) $\mathrm{Al}$ and $\mathrm{Fe}$ inventories within the upper $20 \mathrm{~m}$ increased by $\sim 145$ and $48 \mu \mathrm{mol} \mathrm{m}^{-2}$, respectively (Fig. 4a and c). This increase in the $0-20 \mathrm{~m}$ inventories was consistent but higher than the atmospheric $\mathrm{Al}$ and $\mathrm{Fe}$ fluxes collected on the $\mathrm{R} / \mathrm{V}$ ( $\sim 98$ and $25 \mu \mathrm{mol} \mathrm{m}^{-2}$, respectively; 

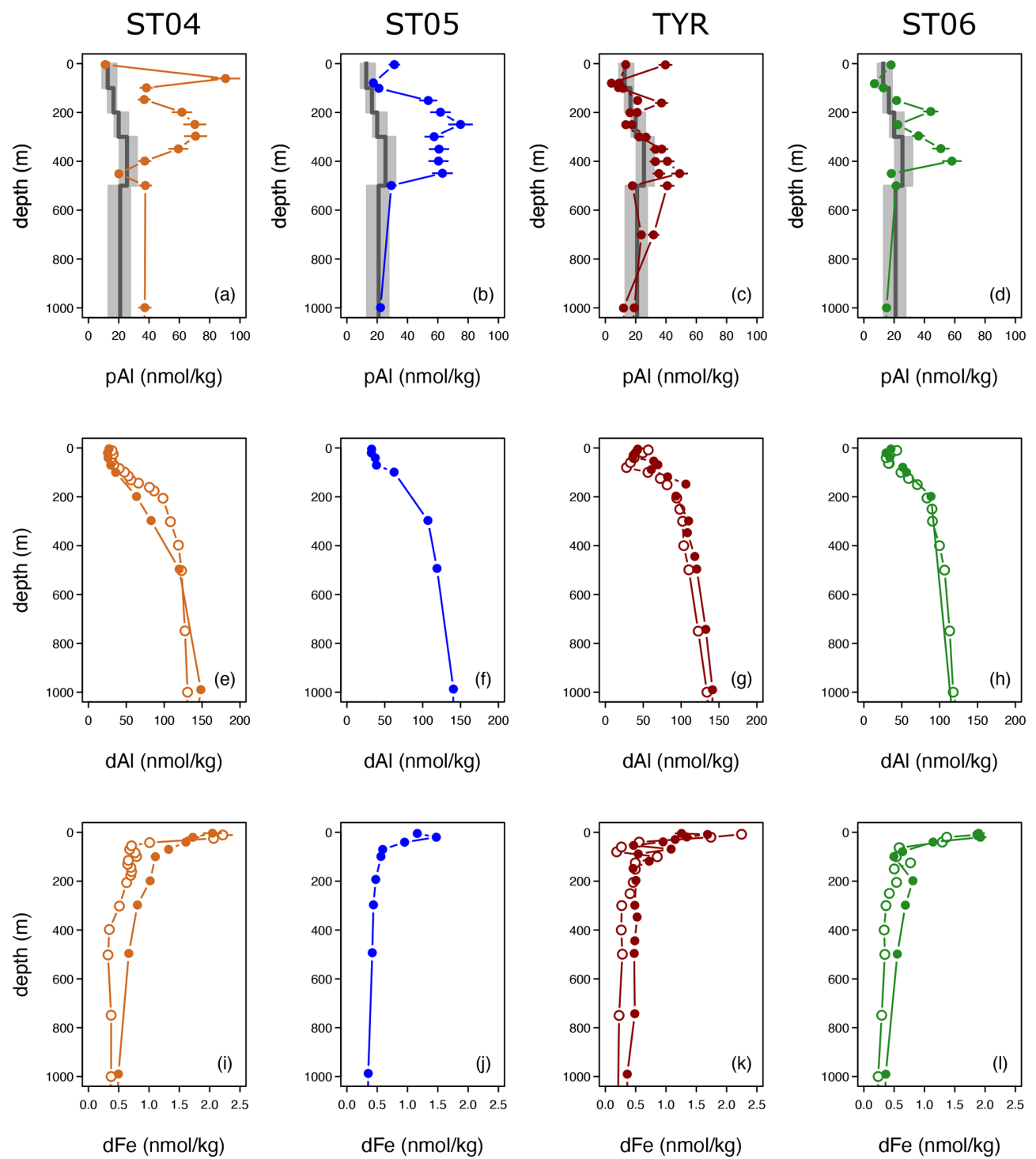

Figure 3. Vertical distribution of $\mathrm{pAl}(\mathbf{a}, \mathbf{b}, \mathbf{c}, \mathbf{d}), \mathrm{dAl}(\mathbf{e}, \mathbf{f}, \mathbf{g}, \mathbf{h})$, and dFe concentrations $(\mathbf{i}, \mathbf{j}, \mathbf{k}, \mathbf{l})$ obtained during the PEACETIME cruise (filled circles) at ST04 (a, e, i), ST05 (b, f, j), TYR (c, g, k), and ST06 (d, h, l). Particulate Al concentrations in (c) correspond to the vertical profiles TYR_2 and TYR_3 (Fig. 5). Previously published vertical profiles of dAl (Rolison et al., 2015) and dFe (Gerringa et al., 2017) obtained at similar locations (Fig. 1) are superimposed (open circles). The median pAl vertical profile (bold lines) is used as a background level (see Sect. 3.3.1 for details), and the first and third quantiles (grey shaded areas) are represented in (a)-(d).

Desboeufs et al., 2021). Based on the increase in the 0-20 m total $\mathrm{Al}$ inventory, and assuming $7.1 \% \mathrm{Al}$ in the dust (Guieu et al., 2002), a total dust input of $55 \mathrm{mg} \mathrm{m}^{-2}$ was derived. Although direct collection of atmospheric dust aerosols represents the most straightforward approach for quantifying the dust flux, it only has a limited spatial coverage. In contrast, the upper water-column inventory integrated most of the patchy rainfalls associated with this large rain front. This difference in time and space integrations is best illustrated by the $\sim 70 \%$ increase in the $0-20 \mathrm{~m} \mathrm{pAl}$ and $\mathrm{pFe}$ inventories observed on 4 June (Fig. 4c), i.e., several hours before the rainfall collected onboard the $\mathrm{R} / \mathrm{V}$ and probably asso- ciated with surrounding precipitation. It must be noted that the water-column approach is also subject to uncertainties, and we cannot exclude an underestimation of the deposition flux due to the rapid sinking of the largest dust particles (e.g., Bressac et al., 2012). However, no evidence of these fast-sinking particles was found deeper in the water column (Fig. 4d), nor within the sediment traps (not shown). 
Table 2. Estimates of the input of pAl, dAl, and dust south of Sardinia (ST04) and over the Tyrrhenian Sea (ST05, TYR, and ST06) based on the 0-1000 $\mathrm{m} \mathrm{Al}_{\text {excess }}$ inventories. The relatively low vertical resolution at TYR_1 precludes accurate estimates.

\begin{tabular}{lrrrrrr}
\hline & $\begin{array}{r}\text { Time since } \\
\text { deposition }^{1}[\mathrm{~d}]\end{array}$ & $\begin{array}{r}\mathrm{Al}_{\text {excess }}^{2}\left[\mu \mathrm{mol} \mathrm{m}^{-2}\right] \\
{\left[\mu \mathrm{mol} \mathrm{m}^{-2}\right]}\end{array}$ & $\begin{array}{r}\mathrm{pAl} \mathrm{input}^{4} \\
{\left[\mu \mathrm{mol} \mathrm{m}^{-2}\right]}\end{array}$ & $\begin{array}{r}\mathrm{dAl} \mathrm{input}^{5} \\
{\left[\mu \mathrm{mol} \mathrm{m}^{-2}\right]}\end{array}$ & $\begin{array}{r}\mathrm{dust} \mathrm{flux}^{6} \\
{\left[\mathrm{~g} \mathrm{~m}^{-2}\right]}\end{array}$ \\
\hline ST04 & 3.6 & 23684 & 485 & 24169 & 363 & 9.2 \\
ST05 & 4.5 & 17773 & 610 & 18382 & 276 & 6.9 \\
TYR_1 & 5.6 & - & - & - & - & - \\
TYR_2 & 6.4 & 3591 & 874 & 4465 & 67 & 1.7 \\
TYR_3 & 8.4 & 4837 & 1143 & 5980 & 90 & 2.3 \\
ST06 & 10.5 & 3126 & 1423 & 4549 & 68 & 1.7 \\
\hline
\end{tabular}

${ }^{1} 11$ May 2017 18:00 UTC is considered as the time of deposition. ${ }^{2}$ Difference between the measured and median 0-1000 m pAl inventories (see Sect. 3.3.1 for details). ${ }^{3}$ Estimates based on the downward $\mathrm{Al}$ flux (1000 m depth; TYR) and assuming a constant flux over time. ${ }^{4}$ Corresponds to $\mathrm{Al}_{\text {excess }}$ corrected for $\mathrm{Al}$ loss. ${ }^{5}$ Estimates based on an $\mathrm{Al}$ fractional solubility of $1.5 \%$ (Wuttig et al., 2013). ${ }^{6}$ Estimates based on an Al composition of the dust of $7.1 \%$ (Guieu et al., 2002).
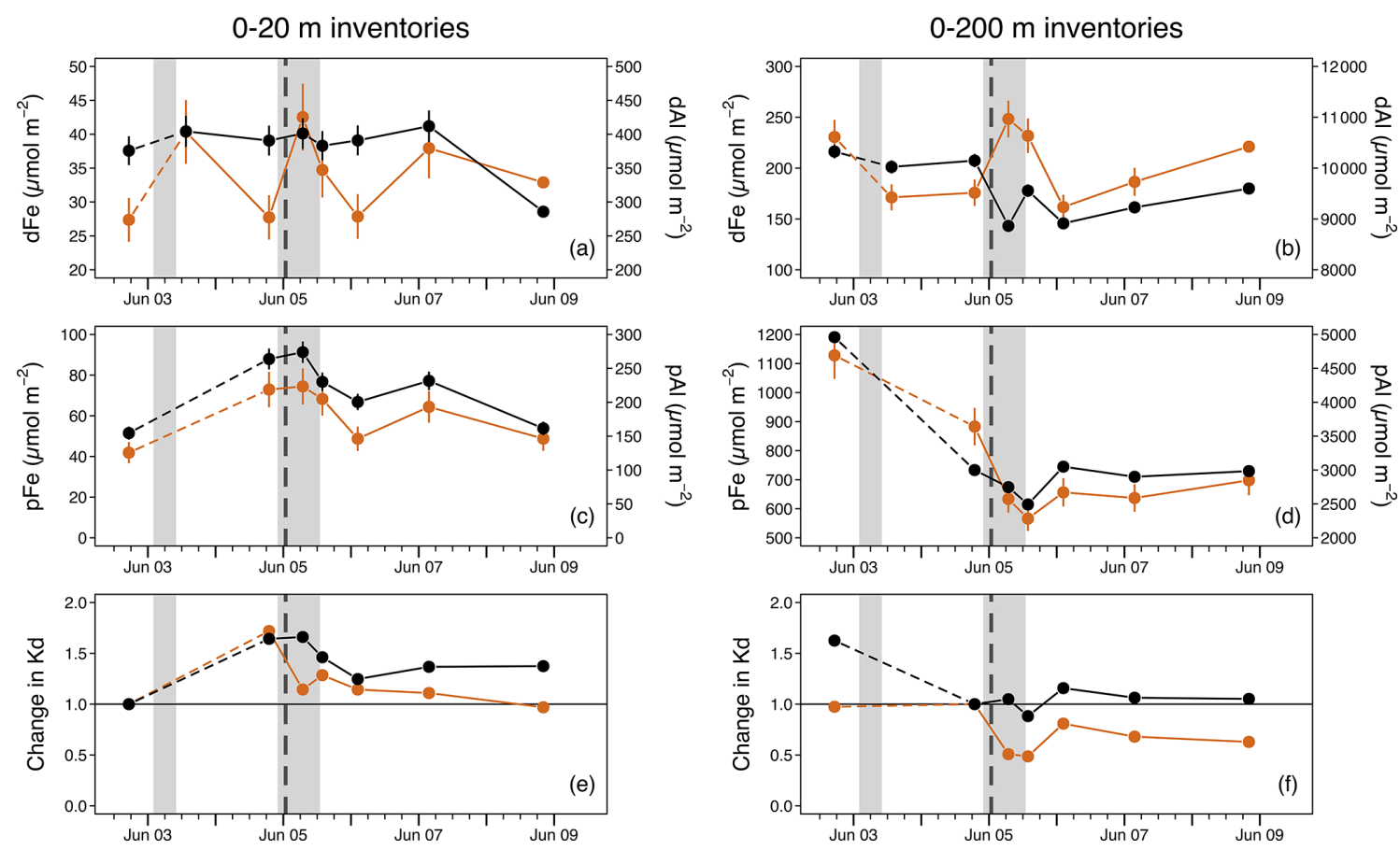

Figure 4. Temporal evolution of the dissolved (a, b) and particulate (c, d) $\mathrm{Al}$ (black) and $\mathrm{Fe}$ (orange) inventories within the 0-20 (a, c, e) and $0-200 \mathrm{~m} \mathrm{(b,} \mathrm{d,} \mathrm{f)} \mathrm{depth} \mathrm{ranges} \mathrm{at} \mathrm{the} \mathrm{FAST} \mathrm{station.} \mathrm{Only} \mathrm{dissolved} \mathrm{inventories} \mathrm{were} \mathrm{measured} \mathrm{on} 3$ June. The relative change in the coefficient of partitioning between the particulate and dissolved fractions (Kd) for $\mathrm{Al}$ and $\mathrm{Fe}$ is presented in (e) and (f). Note that 0-200 $\mathrm{m}$ inventories measured on 4 June (instead of 2 June) were used for the initial Kd in (f) (see Sect. 4.1 for details). Grey vertical bars indicate the two dusty rain events that occurred in the FAST station area. The dotted grey vertical line corresponds to the time of the dusty rainfall sampled on board the R/V (Desboeufs et al., 2021).

\section{Discussion}

\subsection{Advective transport from continental margins in the central Mediterranean Sea}

In the absence of direct atmospheric measurements, large uncertainties are associated with the estimates of the dust deposition flux over the Tyrrhenian Sea. These uncertainties are partly driven by potential additional sources of $\mathrm{pAl}$ and in particular the resuspension of sediments and their advective transport from continental margins (e.g., Misic et al., 2008). The Strait of Sicily, characterized by high turbidity values (Gdaniec et al., 2018), represents a zone of formation for nepheloid layers. Levantine intermediate waters can then act as a conveyor belt that accumulates and transports particles from the eastern to western basin of the Mediterranean Sea (Taillandier et al., 2020). Stations ST04 and ST05, located in the southwestern sector of the Tyrrhenian Sea (i.e., 
the branch of circulation between the Strait of Sicily and the Sardinian Channel), could be potentially impacted by particles driven by this mechanism, contributing to the excess in pAl observed at those stations. Conversely, the central part of the Tyrrhenian Sea is characterized by low turbidity values relative to the rest of the Mediterranean Sea (Gdaniec et al., 2018). During PEACETIME, lateral advection was negligible (Andrea Doglioli, personal communication, 2020) at stations TYR and ST06 precluding any contribution of lithogenic particles other than from dust atmospheric deposition. Evidence of a recent dust deposition event over the Tyrrhenian Sea, traced by the excess in pAl, is discussed in the next section.

\subsection{Dust dynamic in the water column}

In the Tyrrhenian Sea, deposition of dust was evidenced by the $\mathrm{Al}$ and LSi downward fluxes measured at 200 and $1000 \mathrm{~m}$ depth $\sim 5$ to $9 \mathrm{~d}$ after deposition that are $>3$ times higher relative to those measured at ION and FAST at the same depths (Table 1). At TYR, Al and LSi fluxes both increased by $35 \%$ between 200 and $1000 \mathrm{~m}$ depth, suggesting that a significant fraction of the dust particles were rapidly transferred to depth. This trend is consistent with the pAl vertical profiles at the four stations likely impacted by this event, as a subsurface maximum was depicted between $\sim 200$ and $500 \mathrm{~m}$ depth (Fig. 3a-d). In addition, three pAl vertical profiles performed at TYR over $\sim 72 \mathrm{~h}$ showed a continuous decrease in surface pAl concentration of $20 \mu \mathrm{mol} \mathrm{m}^{-2} \mathrm{~d}^{-1}$ that was accompanied by subsequent increases within the $\sim 150$ $500 \mathrm{~m}$ depth layer (Fig. 5). It is worth noting that $\sim 5.6 \mathrm{~d}$ after the event, a remarkably high pAl concentration was observed at $1000 \mathrm{~m}$ depth $\left(\sim 260 \mathrm{nmol} \mathrm{kg}^{-1}\right.$ (TYR_1); not shown), which could indicate that dust particles were sinking at a rate of $\sim 180 \mathrm{~m} \mathrm{~d}^{-1}$. This finding confirms that dust particles can be rapidly transferred to depth either alone (Bressac et al., 2012) or incorporated into biogenic aggregates (e.g., Hamm, 2002; Bressac et al., 2014; Laurenceau-Cornec et al., 2020; van der Jagt et al., 2018). Together, these observations demonstrate the atmospheric origin of pAl observed in the southern Tyrrhenian (rather than sediment resuspension or advective inputs) and confirm that a significant fraction of the dust particles (coarse fraction) can rapidly leave the surface mixed layer when the stratification is strong (Croot et al., 2004; Ternon et al., 2010; Nowald et al., 2015), while the remaining fraction (small-sized particles) likely accumulates along the thermocline until the disruption of the stratification (Migon et al., 2002).

At the FAST station, a dust deposition flux that is 2 orders of magnitude lower $\left(\sim 55 \mathrm{mg} \mathrm{m}^{-2}\right)$ led to an increase of the $0-20 \mathrm{~m} \mathrm{pAl}$ inventory by $78 \%$ (Fig. $4 \mathrm{c}$ ). About $24 \mathrm{~h}$ after deposition, only $\sim 40 \%$ of this signal was still present in the mixed layer. This is consistent with a short residence time in surface water for a significant fraction of the dust, although we cannot exclude the effect of lateral advec-

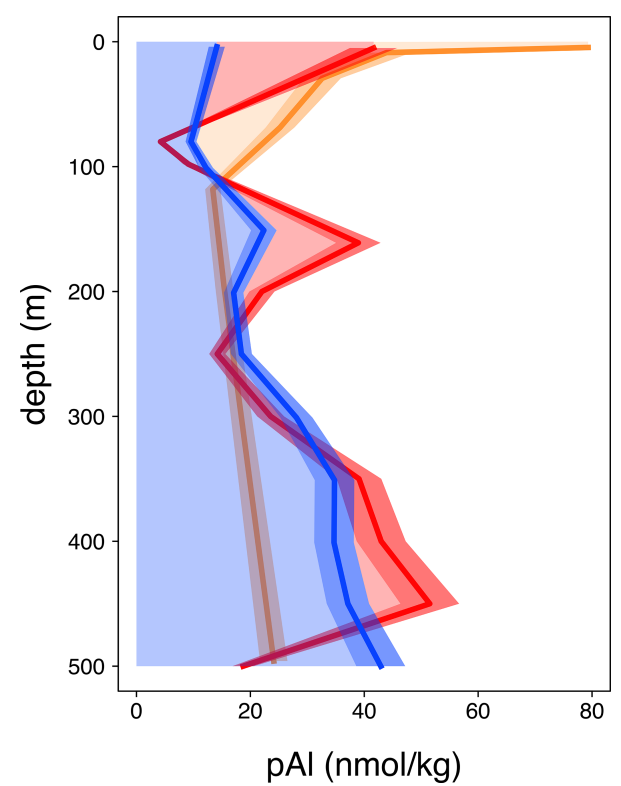

Figure 5. Time evolution of the pAl vertical distribution measured at three different times over $\sim 72 \mathrm{~h}$ at the TYR station. Light shaded areas correspond to the uncertainty in $\mathrm{pAl}$ measurement. The orange (TYR_1), red (TYR_2), and blue (TYR_3) vertical profiles were measured approximately 5.6, 6.4, and $8.4 \mathrm{~d}$ after the dust deposition event, respectively.

tion (Guieu et al., 2020). Deeper in the water column, the trend is more complicated to interpret with a $40 \%$ decrease $\left(\sim 2000 \mu \mathrm{mol} \mathrm{m}^{-2}\right)$ of the $0-200 \mathrm{~m} \mathrm{pAl}$ inventory that occurred before/during deposition (Fig. 4d). This unexpected decrease cannot be explained by the vertical transfer of $\mathrm{pAl}$, as only $\sim 130 \mu \mathrm{mol} \mathrm{m}^{-2}$ of $\mathrm{pAl}$ was exported out of the upper $200 \mathrm{~m}$ over $5 \mathrm{~d}$ (data not shown). On the other hand, a southwestward flow disrupted the water column in the $\sim 25-100 \mathrm{~m}$ depth range from 3 June bringing water masses of distinct properties (Guieu et al., 2020). Therefore, it is likely that the water mass sampled before deposition (2 June) was different from the one sampled during the rest of the time series. For this reason, inventories obtained on 4 June (instead of 2 June) were used as a background level to investigate the temporal evolution of $\mathrm{Kd}(\mathrm{Al})$ and $\mathrm{Kd}(\mathrm{Fe})$ in the $0-200 \mathrm{~m}$ depth range (Fig. 4f).

\subsection{Impact on the dAl inventory}

\subsubsection{Absence of $\mathrm{dAl}$ anomalies}

A relatively large range in $\mathrm{Al}$ fractional solubility (1\%-15\%; defined as the fraction of dust-derived $\mathrm{Al}$ that dissolves in rainwater or seawater) has been reported (e.g., Orians and Bruland, 1986; Baker et al., 2006; Measures et al., 2010; Han et al., 2012; Shelley et al., 2018). Assuming a conservative $\mathrm{Al}$ fractional solubility of $1.5 \%$ in seawater (Wuttig et al., 2013), dust deposition over the Tyrrhenian Sea led to a 
$\mathrm{dAl}$ input ranging between 68 and $363 \mu \mathrm{mol} \mathrm{m}^{-2}$ (Table 2). Further assuming an homogeneous distribution within the 0 $20 \mathrm{~m}$ mixed layer, this dust event represented a dAl input of 3.3-17.7 $\mathrm{nmol} \mathrm{kg}^{-1}$. However, the absence of noticeable anomalies in the long-recognized relationship between surface dAl concentrations and salinity, when compared with published data (Rolison et al., 2015), reveals a limited or transient impact of this event on surface dAl concentrations (Fig. 6). Several mechanisms can be invoked here to explain the absence of dAl signal in the upper water column following the deposition. First, high surface dAl concentrations ( $>20 \mathrm{nmol} \mathrm{kg}^{-1}$ ) might mask any additional input. At ST06, the putative dAl input of $3.3 \mathrm{nmol} \mathrm{kg}^{-1}$ (Table 2) is within the range of variability of both published and observed surface concentrations (30-43 nmol kg${ }^{-1}$; Fig. 3h). At the other end (ST04), the situation is different with a dAl input of $17.7 \mathrm{nmol} \mathrm{kg}{ }^{-1}$ that would represent more than $55 \%$ of predepositional surface dAl concentrations $\left(31-32 \mathrm{nmol} \mathrm{kg}^{-1}\right.$; Rolison et al., 2015). Considering the short time lag between deposition and observations at ST04 $(\sim 3.6 \mathrm{~d})$, and the low horizontal advection at the TYR station area (Andrea Doglioli, personal communication, 2020), it is unlikely that advective mixing diluted any elevated dAl signal from this event. Deeper in the water column, no clear trend was obtained with subsurface dAl concentrations lower (ST04; Fig. 3e) or slightly higher than background levels (TYR; Fig. 3g). Similarly, no noticeable increase in $\mathrm{dAl}$ could be observed at the FAST station in the mixed layer (Figs. 4a and 6). In contrast to $\mathrm{Kd}(\mathrm{Fe}), \mathrm{Kd}(\mathrm{Al})$ was still higher than the pre-depositional value $4 \mathrm{~d}$ after deposition (Fig. 4e), potentially reflecting a lower fractional solubility for dust-derived $\mathrm{Al}$ relative to $\mathrm{Fe}$ and/or a higher removal rate for dAl. Below the mixed layer, $\mathrm{Kd}(\mathrm{Al})$ remained relatively constant and similar to initial value (Fig. 4f). Together, these observations indicate that wet deposition of dust over the FAST station area had a limited impact on the $\mathrm{dAl}$ inventory.

\subsubsection{Drivers of the rapid removal of dAl}

$\mathrm{An} \mathrm{Al}$ fractional solubility of $5 \%$ was measured in rainwater for dust aerosols collected at the FAST station (Desboeufs et al., 2021), i.e., well above the conservative value of $1.5 \%$ obtained for a dust flux of $10 \mathrm{~g} \mathrm{~m}^{-2}$ (Wuttig et al., 2013), and used to estimate dAl inputs over the Tyrrhenian Sea. This confirms that dust loading partly controls the $\mathrm{Al}$ fractional solubility (e.g., Shelley et al., 2018). In addition, a biological control on dAl distribution in the Mediterranean Sea has been proposed to explain the strong coupling between dAl and orthosilicic acid $\left(\mathrm{Si}(\mathrm{OH})_{4}\right)$ in subsurface waters (Chou and Wollast, 1997; Rolison et al., 2015). Several laboratory and field studies have demonstrated that marine phytoplankton, in particular diatoms (mainly incorporated into the frustules; Gehlen et al., 2002), can take up and/or scavenge dAl (Mackenzie et al., 1978; Orians and Bruland, 1986; Moran and Moore, 1988b; Loucaides et al., 2010; Twining

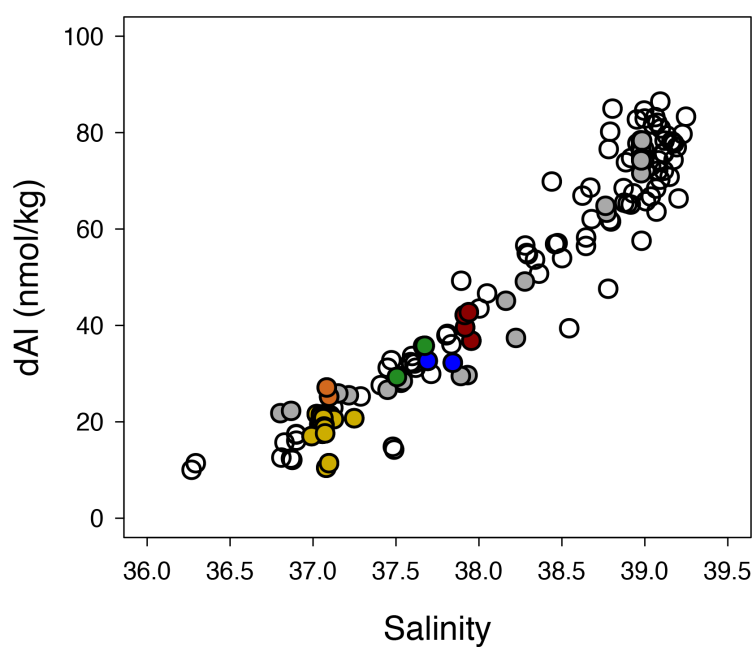

Figure 6. Dissolved Al concentrations versus salinity measured in the upper $30 \mathrm{~m}$ of the Mediterranean Sea during the PEACETIME (filled circles), 64PE370, and 64PE374 cruises (open circles; Rolison et al., 2015). Yellow, orange, blue, red, and green circles correspond to data obtained at FAST, ST04, ST05, TYR, and ST06, respectively (Fig. 1). Grey circles correspond to data obtained during the PEACETIME cruise at the other stations.

et al., 2015b; Wuttig et al., 2013; Liu et al., 2019). To investigate the respective role of particle adsorption and biological uptake in removing $\mathrm{dAl}, \mathrm{Al}$ was compared to $\mathrm{Fe}-$ a particle-reactive and bioactive element (Tagliabue et al., 2017) predominantly of crustal origin in the Mediterranean $\mathrm{Sea}$ - through the $\mathrm{Fe} / \mathrm{Al}$ content of suspended and sinking particles collected at different depth horizons (Fig. 7).

For suspended particles, the median $\mathrm{Fe} / \mathrm{Al}$ ratio was maximum within the surface mixed layer and minimum at the DCM (60-100 m; Fig. 7a), highlighting a strong contrast in $\mathrm{Fe} / \mathrm{Al}$ between the diatom-dominated particle assemblage at the DCM (Marañón et al., 2021) and detrital and lithogenic particles in the rest of the water column. This contrast supports the significant role played by phytoplankton, and in particular diatoms, in accumulating Al via active uptake (Gehlen et al., 2002; Liu et al., 2019) and/or adsorption onto cell membranes (Dammshäuser and Croot, 2012; Twining et al., 2015b). Note that we cannot exclude atmospheric input of BSi associated with dust particles (e.g., Folger et al., 1967). Regarding sinking particles, the relationship between the $\mathrm{Fe} / \mathrm{Al}$ ratio and the relative proportion of $\mathrm{LSi}$ and $\mathrm{BSi}$ was relatively well represented by a two-component model, with $\mathrm{BSi}$ having a fixed $\mathrm{Fe} / \mathrm{Al}$ ratio of $0.21 \mathrm{~mol} \mathrm{~mol}^{-1}$ (value observed in the diatom-dominated DCM; Fig. 7a) and LSi having a $\mathrm{Fe} / \mathrm{Al}$ ratio ranging between 0.26 (dusty rainwater sampled at FAST; Desboeufs et al., 2021) and $0.30 \mathrm{~mol} \mathrm{~mol}^{-1}$ (Saharan dust end-member; Guieu et al., 2002) (Fig. 7b). Sparse $\mathrm{Al} / \mathrm{Si}$ ratios available for natural diatom communities range between $\sim 1$ and $10 \mu \mathrm{mol} \mathrm{mol}^{-1}$ (van Bennekom et al., 1989; Gehlen et al., 2002; Koning et al., 2007). Using this 

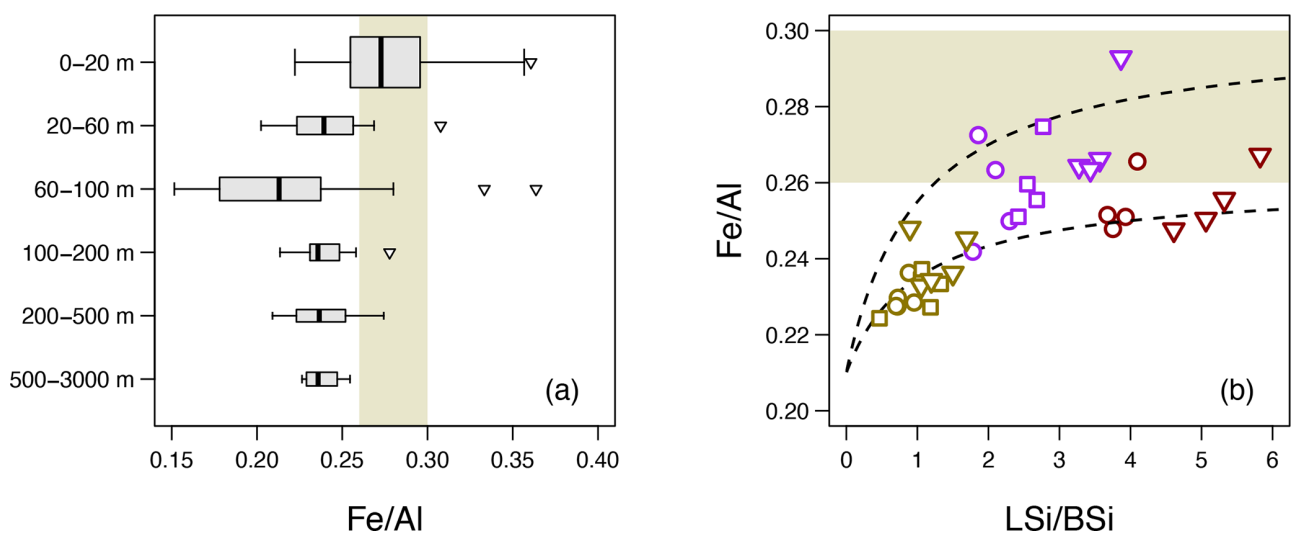

Figure 7. (a) Box-and-whisker plot of the Fe/Al molar ratio $\left(\mathrm{mol} \mathrm{mol}^{-1}\right)$ for suspended particles collected at TYR, ION, and FAST. The $\mathrm{Fe} / \mathrm{Al}$ median values are $0.27(n=37 ; 0-20 \mathrm{~m}), 0.24(n=13 ; 20-60 \mathrm{~m}), 0.21(n=17 ; 60-100 \mathrm{~m}), 0.24(n=12 ; 100-200 \mathrm{~m}), 0.24(n=9$; $200-500 \mathrm{~m})$, and $0.24(n=10 ; 500-3000 \mathrm{~m})$. For clarity, two outliers $(\mathrm{Fe} / \mathrm{Al}=0.50$ and 1.02$)$ observed in the $0-20 \mathrm{~m}$ depth range are not represented. (b) Fe/Al versus $\mathrm{LSi} / \mathrm{BSi}$ molar ratios $\left(\mathrm{mol} \mathrm{mol}^{-1}\right.$ ) of sinking particles collected at $\sim 200 \mathrm{~m}$ (circles), $500 \mathrm{~m}$ (squares), and $1000 \mathrm{~m}$ depth (triangles) at the stations TYR (red), ION (purple), and FAST (yellow). The two dotted black curves correspond to a twocomponent model, with BSi having a fixed Fe/Al molar ratio of $0.21 \mathrm{~mol} \mathrm{~mol}^{-1}$ (i.e., value observed in the DCM in a) and LSi having a fixed Fe/Al molar ratio of 0.26 (lower curve; Desboeufs et al., 2021) or $0.30 \mathrm{~mol} \mathrm{~mol}^{-1}$ (upper curve; Guieu et al., 2002). Yellow shaded areas in (a) and (b) represent the range in $\mathrm{Fe} / \mathrm{Al}$ molar ratio proposed for Saharan dust, with the lower limit corresponding to dust aerosols collected at FAST $\left(0.26 \mathrm{~mol} \mathrm{~mol}^{-1}\right.$; Desboeufs et al., 2021) and the upper limit to the Saharan dust end-member $\left(0.30 \mathrm{~mol} \mathrm{~mol}^{-1}\right.$; Guieu et al., 2002).

range of values, the $\mathrm{Al}$ downward flux at $200 \mathrm{~m}$ depth driven by (and incorporated into) BSi would represent only $0.1-$ $1.1 \mu \mathrm{mol} \mathrm{m} \mathrm{m}^{-2} \mathrm{~d}^{-1}$, i.e., $\sim 0.2 \%-3.3 \%$ of the total Al flux. This difference with our conservative estimates of dAl inputs over the Tyrrhenian Sea, by 2 orders of magnitude (68$371 \mu \mathrm{mol} \mathrm{m}^{-2}$; Table 2), indicates that adsorption onto biogenic particles (including $\mathrm{BSi}$ ), rather than active uptake by diatoms, was likely the main sink for $\mathrm{dAl}$ in that region.

\subsection{Vertical pattern in dFe input}

\subsubsection{Transient dFe increase in the surface mixed layer}

The absence of pre-depositional observations in the Tyrrhenian Sea is more problematic for $\mathrm{Fe}$ compared to $\mathrm{Al}$, as no clear longitudinal trend has been reported in the Mediterranean Sea for that element. Dissolved Fe vertical profiles were thus compared to previously published data that were obtained at similar locations (Fig. 1) and at the same period of the year for ST04 (mid-April) but about 2 months later at TYR and ST06 (early August) (Gerringa et al., 2017). Consequently, this approach ignores interannual and seasonal variabilities in $\mathrm{dFe}$ and cannot be used to strictly quantify $\mathrm{dFe}$ input but remains valuable to investigate its magnitude and vertical distribution.

Assuming a Fe content of $4.45 \%$ in dust (Guieu et al., 2002), this dust event over the Tyrrhenian Sea represented a Fe input of $\sim 1300-7000 \mu \mathrm{mol} \mathrm{m}^{-2}$ (with a short retention time within the sea surface microlayer; Tovar-Sánchez et al., 2020). Yet, dFe concentrations within the surface mixed layer were at background levels (ST04 and ST06) or slightly below
(TYR) (Fig. 3i-1). These observations made $\sim 3$ to $10 \mathrm{~d}$ after deposition indicate that this event had no impact on $\mathrm{dFe}$ in the surface mixed layer at a timescale of days. At a shorter timescale, sampling performed at a high temporal resolution at the FAST station revealed two distinct increases of the $0-20 \mathrm{~m} \mathrm{dFe}$ inventory that occurred during $\left(+13 \mu \mathrm{mol} \mathrm{m}^{-2}\right)$ and about $6 \mathrm{~h}$ after deposition $\left(+15 \mu \mathrm{mol} \mathrm{m}{ }^{-2}\right.$; Fig. $\left.4 \mathrm{a}\right)$. These $\sim 50 \%$ increases were only transient, and the predepositional level was rapidly recovered. Considering that Fe cycling in this LNLC system is dominated by physicochemical rather than biological processes, our findings are consistent with rapid scavenging of $\mathrm{dFe}$ in surface Mediterranean waters following dust deposition, as already reported in some mesocosm and minicosm dust addition experiments (Wagener et al., 2010; Wuttig et al., 2013; Bressac and Guieu, 2013). Overall, the Fe-binding ligand pool is nearly saturated in surface Mediterranean waters (Gerringa et al., 2017). As a consequence, any new input of $\mathrm{dFe}$ will tend to precipitate, pointing to the importance of the initial $\mathrm{dFe}$ and $\mathrm{Fe}$-binding ligand concentrations in setting the net effect of dust input on dFe in the surface mixed layer (Ye et al., 2011; Wagener et al., 2010; Wuttig et al., 2013).

\subsubsection{Enrichment in dFe below the surface mixed layer}

A key feature in the southern Tyrrhenian was the systematic subsurface excess in $\mathrm{dFe}$ observed from $\sim 40$ (ST04) and $200 \mathrm{~m}$ depth (TYR and ST06) (Fig. 3i-1) and mirroring the vertical distribution of $\mathrm{Al}_{\text {excess }}$ (Fig. 3a-d). Similarly, wet dust deposition over the FAST station area led to a net 
input of dFe mainly below the mixed layer, as revealed by the opposite trends in $\mathrm{Kd}(\mathrm{Fe})$ observed in the $0-20 \mathrm{~m}$ and $0-200 \mathrm{~m}$ depth ranges (Fig. 4e-f). This increase in $\mathrm{dFe}$ relative to $\mathrm{pFe}$ was persistent on a timescale of days (Fig. 4f) and was primarily driven by dust dissolution (Fig. 4b) rather than ballasting of preexisting pFe (Fig. 4d), as evidenced by the low-export Fe flux collected at $200 \mathrm{~m}$ depth $(1.7-$ $\left.12.3 \mu \mathrm{mol} \mathrm{m}^{-2} \mathrm{~d}^{-1}\right)$. This systematic excess in $\mathrm{dFe}$ observed below the mixed layer and extending to $1000 \mathrm{~m}$ suggests that the mechanisms involved are independent of the dust flux that differed by 2 orders of magnitude - and timescale considered (hours to weeks). Such dust-related subsurface enrichment in $\mathrm{dFe}$ (without enhanced surface $\mathrm{dFe}$ concentrations) has already been observed in the subarctic Pacific and tropical North Atlantic. This feature was attributed either to low oxygen levels, allowing Fe(II) to stay in solution (Schallenberg et al., 2017), or to remineralization of organic matter formed in the dust-laden surface ocean (Measures et al., 2008; Fitzsimmons et al., 2013); two mechanisms that cannot be invoked here considering the oxygen levels in subsurface $(170-200 \mu \mathrm{M})$ are the short timescale considered and the low mesopelagic Fe regeneration efficiency (Bressac et al., 2019).

To account for this $\mathrm{dFe}$ excess below the surface mixed layer, dust-bearing $\mathrm{Fe}$ must continue to dissolve as dust particles settle through the mixed layer and reach the mesopelagic. The short residence time for dust in surface water (Sect. 4.1) and the presence of a "refractory" Fe pool within dust particles that dissolves over several days (Wagener et al., 2008) confirm that dust dissolution can occur in subsurface. It is also likely that the low particle concentration encountered at these depths relative to the particle-rich surface waters at the time of deposition prevented rapid removal of dFe (e.g., Spokes et al., 1994; Bonnet and Guieu, 2004). Furthermore, the Fe-binding ligand pool is pivotal in setting the Fe fractional solubility (Rijkenberg et al., 2008; Wagener et al., 2008, 2010; Ye et al., 2011; Fishwick et al., 2014), and its magnitude, composition, and distribution likely shape patterns of dFe supply. While nearly saturated in surface, the Fe-binding ligand pool is in relatively large excess to $\mathrm{dFe}$ in subsurface Mediterranean waters (Gerringa et al., 2017) and hence available to stabilize new dFe. Importantly, this subsurface pool is constantly replenished by bacterial degradation of sinking biogenic particles (Boyd et al., 2010; Velasquez et al., 2016; Bressac et al., 2019; Whitby et al., 2020). Thus, there is a permanent resetting of the ligand pool while dust particles settle (Bressac et al., 2019), and, conceptually, we can imagine that the binding equilibrium between available ligands and $\mathrm{Fe}$ is rarely reached at these depths and timescale. This fundamental difference in the surface waters (and batch experiments) could explain the high Fe fractional solubility of $4.6 \%-13.5 \%$ derived in the southern Tyrrhenian from the increase in the $0-1000 \mathrm{~m}$ dFe inventories (relative to published data; Fig. 3i-l) and assuming $4.45 \% \mathrm{Fe}$ in the dust (Guieu et al., 2002).
By feeding the subsurface $\mathrm{dFe}$ reservoir, dust deposition could represent an indirect supply route for the surface ocean through vertical mixing and diapycnal diffusion (e.g., Tagliabue et al., 2014). However, the residence time of this dustderived reservoir remains an open question. Relatively low subsurface $\mathrm{dFe}$ concentrations observed at the basin-scale $\left(<0.5 \mathrm{nmol} \mathrm{kg}^{-1}\right.$; Supplement Fig. S2c), compared to Atlantic waters for instance (Gerringa et al., 2017), support the argument in favor of a short residence time. Scavenging by sinking (dust) particles (e.g., Wagener et al., 2010; Bressac et al., 2019) and bacterial removal of humic-like ligands (Dulaquais et al., 2018; Whitby et al., 2020) represent two potential sinks for this subsurface $\mathrm{dFe}$ reservoir that need to be explored.

\section{Conclusions}

During the PEACETIME cruise performed in May-June 2017 in the western and central Mediterranean, we observed two atmospheric wet deposition events while measuring $\mathrm{Al}$ and $\mathrm{Fe}$ water-column distributions, providing important insights into the timescale and pattern of $\mathrm{dAl}$ and $\mathrm{dFe}$ inputs from African dust in the remote Mediterranean Sea. The water-column $\mathrm{Al}$ inventories were successfully utilized to assess dust deposition fluxes, complementing atmospheric measurements and the "fast-action" strategy used during the campaign to directly sample dusty rain events. Our observations show that $\mathrm{dAl}$ removal through adsorption onto biogenic particles was dominant over dAl released from dust at a timescale of hours to days. While surface dAl concentrations reflect seasonal changes and large-scale patterns in dust deposition, this finding indicates that this tracer may not be appropriate to trace the imprint of a single dust deposition event in highly dust-impacted areas. Furthermore, dust deposition only represented a significant input of $\mathrm{dFe}$ in the surface mixed layer on a timescale of hours. On a longer timescale (days/weeks), dFe inputs occurred primarily below the surface mixed layer extending to $1000 \mathrm{~m}$ depth where the Fe-binding ligand pool likely in excess of $\mathrm{dFe}$ allows any additional input of $\mathrm{dFe}$ to be stabilized. This mechanism may represent an additional pathway of dFe resupply for the surface ocean (through vertical mixing and diapycnal diffusion), although the residence time of this dust-derived $\mathrm{dFe}$ reservoir still needs to be investigated.

Data availability. Underlying research data are being used by researcher participants of the PEACETIME campaign to prepare other papers, and therefore data are not publicly accessible at the time of publication. Data will be accessible once the special issue is completed (http://www.obs-vlfr.fr/proof/php/PEACETIME/peacetime. php, last access 13 December 2021). The policy of the database is detailed here: http://www.obs-vlfr.fr/proof/dataconvention.php, last access 13 December 2021 and https://www.seanoe.org/data/00645/ 75747/ (last access: 13 December 2021, Guieu et al., 2020). 
Supplement. The supplement related to this article is available online at: https://doi.org/10.5194/bg-18-6435-2021-supplement.

Author contributions. MB, TW, and CG designed the study. MB wrote the manuscript. MB, TW, NL, ATS, CR, VT, SA, SG, and AD collected and/or analyzed the samples. FD and KD interpreted the atmospheric data. All the authors commented on and contributed to the improvement of the manuscript.

Competing interests. The contact author has declared that neither they nor their co-authors have any competing interests.

Disclaimer. Publisher's note: Copernicus Publications remains neutral with regard to jurisdictional claims in published maps and institutional affiliations.

Special issue statement. This article is part of the special issue "Atmospheric deposition in the low-nutrient-low-chlorophyll (LNLC) ocean: effects on marine life today and in the future (ACP/BG interjournal SI)". It is not associated with a conference.

Acknowledgements. We thank the captain and crew of the $\mathrm{R} / \mathrm{V}$ Pourquoi Pas?, the DT INSU for the design and preparation of the mooring line, and Nagib Bhairy, Guillaume De Liège, and Gilles Rougier for their help with the mooring. Hélène Ferré and the AERIS/SEDOO service are acknowledged for real-time collection during the cruise of maps produced from operational satellites and models used in this study, with appreciated contributions of EUMETSAT and ICARE for MSG/SEVIRI products, Météo-France for ARPEGE model outputs, the WMO SDS-WAS operated by the Barcelona Supercomputing Center (BSC) for DREAM and NMMB model outputs, and the AM\&WFG of the University of Athens for SKIRON model outputs. This study is a contribution to the PEACETIME project (http://peacetime-project.org; last access: 25 October 2021), a joint initiative of the MERMEX and ChArMEx components supported by CNRS-INSU, IFREMER, CEA, and MétéoFrance as part of the decadal program MISTRALS coordinated by INSU. PEACETIME was endorsed as a process study by GEOTRACES and is also a contribution to IMBER and SOLAS international programs. The constructive comments during the review process of Thomas Holmes, an anonymous referee, Silvia Becagli, and Christine Klass are much appreciated.

Financial support. This research has been supported by the Horizon 2020 (IRON-IC (grant no. 626734)) and the Horizon 2020 (DUSC3 (grant no. 708119)). The project leading to this publication received funding from CNRS-INSU, IFREMER, CEA, and MétéoFrance as part of the program MISTRALS coordinated by INSU and from the European FEDER fund (grant no. 1166-39417).
Review statement. This paper was edited by Silvia Becagli and reviewed by Thomas Holmes and one anonymous referee.

\section{References}

Acker, J. G. and Leptoukh, G.: Online analysis enhances use of NASA Earth science data, Eos Trans. AGU, 88, 14-17, https://doi.org/10.1029/2007EO020003, 2007.

Anderson, R. F., Cheng, H., Edwards, R. L., Fleisher, M. Q., Hayes, C. T., Huang, K.-F., Kadko, D., Lam, P. J., Landing, W. M., Lao, Y., Lu, Y., Measures, C. I., Moran, S. B., Morton, P. L., Ohnemus, D. C., Robinson, L. F., and Shelley, R. U.: How well can we quantify dust deposition to the ocean?, Philos. T. R. Soc. A, 374, 20150285, https://doi.org/10.1098/rsta.2015.0285, 2016.

Baker, A. R. and Croot P. L.: Atmospheric and marine controls on aerosol iron solubility in seawater, Mar. Chem., 120, 4-13, https://doi.org/10.1016/j.marchem.2008.09.003, 2010.

Baker, A. R., Jickells, T. D., Witt, M., and Linge, K. L.: Trends in the solubility of iron, aluminium, manganese and phosphorus in aerosol collected over the Atlantic Ocean, Mar. Chem., 98, 4358, https://doi.org/10.1016/j.marchem.2005.06.004, 2006.

Bonnet, S. and Guieu, C.: Dissolution of atmospheric iron in seawater, Geophy. Res. Lett., 31, L03303, https://doi.org/10.1029/2003GL018423, 2004.

Bonnet, S. and Guieu, C.: Atmospheric forcing on the annual iron cycle in the Mediterranean Sea. A one-year survey, J. Geophys. Res., 111, C09010, https://doi.org/10.1029/2005JC003213, 2006.

Boyd, P. W., Ibisanmi, E., Sander, S. G., Hunter, K. A., and Jackson, G. A.: Remineralization of upper ocean particles: Implications for iron biogeochemistry, Limnol. Oceanogr., 55, 1271-1288, https://doi.org/10.4319/lo.2010.55.3.1271, 2010.

Bressac, M. and Guieu, C.: Post-depositional processes: What really happens to new atmospheric iron in the ocean surface?, Global Biogeochem. Cy., 27, 859-870, https://doi.org/10.1002/gbc.20076, 2013.

Bressac, M., Guieu, C., Doxaran, D., Bourrin, F., Obolensky, G., and Grisoni, J. M.: A mesocosm experiment coupled with optical measurements to assess the fate and sinking of atmospheric particles in clear oligotrophic waters, Geo.-Mar. Lett., 32, 153164, https://doi.org10.1007/s00367-011-0269-4, 2012.

Bressac, M., Guieu, C., Doxaran, D., Bourrin, F., Desboeufs, K., Leblond, N., and Ridame, C.: Quantification of the lithogenic carbon pump following a simulated dust-deposition event in large mesocosms, Biogeosciences, 11, 1007-1020, https://doi.org/10.5194/bg-11-1007-2014, 2014.

Bressac, M., Guieu, C., Ellwood, M. J., Tagliabue, A., Wagener, T., Laurenceau Cornec, E. C., Whitby, H., Sarthou, G., and Boyd, P. W.: Resupply of mesopelagic dissolved iron controlled by particulate iron composition, Nat. Geosci., 12, 995-1000, https://doi.org/10.1038/s41561-019-0476-6, 2019.

Buat-Ménard, P., Davies, J., Remoudaki, E., Miquel, J. C., Bergametti, G., Lambert, C. E., Ezat, U., Quetel, C., La Rosa, J., and Fowler, S. W.: Non-steady-state biological removal of atmospheric particles from Mediterranean surface waters, Nature, 340, 131-134, https://doi.org/10.1038/340131a0, 1989.

Chou, L. and Wollast, R.: Biogeochemical behavior and mass balance of dissolved aluminum in the western 
Mediterranean Sea, Deep-Sea Res. Pt. II, 44, 741-768, https://doi.org/10.1016/S0967-0645(96)00092-6, 1997.

Christensen, J. H.: The Danish eulerian hemispheric model - A three-dimensional air pollution model used for the Arctic, Atmos. Environ., 31, 4169-4191, https://doi.org/10.1016/S13522310(97)00264-1, 1997.

Conway, T. M. and John, S. G.: Quantification of dissolved iron sources to the North Atlantic Ocean, Nature, 511, 212-215, https://doi.org/10.1038/nature13482, 2014.

Croot, P. L., Streu, P., and Baker, A. R.: Short residence time for iron in surface seawater impacted by atmospheric dry deposition from Saharan dust events, Geophys. Res. Lett., 31, L23S08, https://doi.org/10.1029/2004GL020153, 2004.

Cutter, G. A., Andersson, P., Codispoti, L., Croot, P., Francois, R., Lohan, M., Obata, H., and Rutgers van der Loeff, M.: Sampling and Sample-handling Protocols for GEOTRACES Cruises, 2010 GEOTRACES Standards and Intercalibration Committee, 2010.

Dammshäuser, A. and Croot, P. L.: Low colloidal associations of aluminium and titanium in surface waters of the tropical Atlantic, Geochim. Cosmochim. Ac., 96, 304-318, https://doi.org/10.1016/j.gca.2012.07.032, 2012.

Dammshäuser, A., Wagener, T., and Croot, P. L.: Surface water dissolved aluminum and titanium: Tracers for specific time scales of dust deposition to the Atlantic?, Geophys. Res. Lett., 38, L24601, https://doi.org/10.1029/2011GL049847, 2011.

Davies, J. E. and Buat-Ménard, P.: Impact of atmospheric deposition on particulate manganese and aluminium distribution in northwestern Mediterranean surface water, Glob. Planet. Change, 3, 35-45, https://doi.org/10.1016/0921-8181(90)90054-G, 1990.

de Leeuw, G., Guieu, C., Arneth, A., Bellouin, N., Bopp, L., Boyd, P. W., Denier van der Gon, H. A. C., Desboeufs, K. V., Dulac, F., Cristina Facchini, M. C., Gantt, B., Langmann, B., Mahowald, N. M., Marañón, E., O’Dowd, C., Olgun, N., Pulido-Villena, E., Rinaldi, M., Stephanou, E.G., and Wagener, T.: Ocean-Atmosphere interactions of particles, in: Ocean-Atmosphere Interactions of Gases and Particles, edited by: Liss, P. and Johnson, M., Springer Earth System Sciences, Springer Berlin Heidelberg, 171-246, https://doi.org/10.1007/978-3-642-25643-1_4, 2014.

Desboeufs, K., Bon Nguyen, E., Chevaillier, S., Triquet, S., and Dulac, F.: Fluxes and sources of nutrients and trace metal atmospheric deposition in the northwestern Mediterranean, Atmos. Chem. Phys., 18, 14477-14492, https://doi.org/10.5194/acp-1814477-2018, 2018.

Desboeufs, K., Fu, F., Bressac, M., Tovar-Sánchez, A., Triquet, S., Doussin, J.-F., Giorio, C., Chazette, P., Disnaquet, J., Feron, A., Formenti, P., Maisonneuve, F., Rodri'guez-Romero, A., Zapf, P., Dulac, F., and Guieu, C.: Wet deposition in the remote western and central Mediterranean as a source of trace metals to surface seawater, Atmos. Chem. Phys. Discuss. [preprint], https://doi.org/10.5194/acp-2021-624, in review, 2021.

Donaghay, P. L., Liss, P. S., Duce, R. A., Kester, D. R., Hanson, A. K., Villareal, T., Tindale, N. W., and Gifford, D. J.: The role of episodic atmospheric nutrient inputs in the chemical and biological dynamics of oceanic ecosystems, Oceanography, 4, 62-70, https://doi.org/10.5670/oceanog.1991.04, 1991.

Duce, R. A., Liss, P. S., Merrill, J. T., Atlas, E. L., Buat-Menard, P., Hicks, B. B., Miller, J. M., Prospero, J. M., Arimoto, R., Church, T. M., Ellis, W., Galloway, J. N., Hansen, L., Jickells, T. D., Knap, A. H., Reinhardt, K. H., Schneider, B. Soudine, A., Tokos,
J. J., Tsunogai, S., Wollast, R., and Zhou, M.: The atmospheric input of trace species to the world ocean, Global Biogeochem. Cy., 5, 193-259, https://doi.org/10.1029/91GB01778, 1991.

Dulac, F., Tanré, D., Bergametti, G., Buat-Ménard, P., Desbois, M., and Sutton, D.: Assessment of the African airborne dust mass over the western Mediterranean Sea using Meteosat data, J. Geophys. Res.-Atmos., 97, 2489-2506, https://doi.org/10.1029/91JD02427, 1992.

Dulaquais, G., Waeles, M., Gerringa, L. J., Middag, R., Rijkenberg, M. J., and Riso, R.: The biogeochemistry of electroactive humic substances and its connection to iron chemistry in the North East Atlantic and the Western Mediterranean Sea, J. Geophys. Res.-Ocean., 123, 5481-5499, https://doi.org/10.1029/2018JC014211, 2018.

Fishwick, M. P., Sedwick, P. N., Lohan, M. C., Worsfold, P. J., Buck, K. N., Church, T. M., and Ussher, S. J.: The impact of changing surface ocean conditions on the dissolution of aerosol iron, Global Biogeochem. Cy., 28, 1235-1250, https://doi.org/10.1002/2014GB004921, 2014.

Fitzsimmons, J. N., Zhang, R., and Boyle, E. A.: Dissolved iron in the tropical North Atlantic Ocean, Mar. Chem., 154, 87-99, https://doi.org/10.1016/j.marchem.2013.05.009, 2013.

Flemming, J., Huijnen, V., Arteta, J., Bechtold, P., Beljaars, A., Blechschmidt, A.-M., Diamantakis, M., Engelen, R. J., Gaudel, A., Inness, A., Jones, L., Josse, B., Katragkou, E., Marecal, V., Peuch, V.- H., Richter, A., Schultz, M. G., Stein, O., and Tsikerdekis, A.: Tropospheric chemistry in the Integrated Forecasting System of ECMWF, Geosci. Model Dev., 8, 975-1003, https://doi.org/10.5194/gmd-8-975-2015, 2015.

Folger, D. W., Burckle, L. H., and Heezen, B. C.: Opal phytoliths in a North Atlantic dust fall, Science, 155, 1243-1244, https://doi.org/10.1126/science.155.3767.1243, 1967.

Gazeau, F., Ridame, C., VanWambeke, F., Alliouane, S., Stolpe, C., Irisson, J.-O., Marro, S., Grisoni, J.-M., De Liège, G., Nunige, S., Djaoudi, K., Pulido-Villena, E., Dinasquet, J., Obernosterer, I., Catala, P., and Guieu, C.: Impact of dust addition on Mediterranean plankton communities under present and future conditions of $\mathrm{pH}$ and temperature: an experimental overview, Biogeosciences, 18, 5011-5034, https://doi.org/10.5194/bg-185011-2021, 2021.

Gdaniec, S., Roy-Barman, M., Foliot, L., Thil, F., Dapoigny, A., Burckel, P., Garcia-Orellana, J., Masqué, P., Mörth, C.M., and Andersson, P. S.: Thorium and protactinium isotopes as tracers of marine particle fluxes and deep water circulation in the Mediterranean Sea, Mar. Chem., 199, 12-23, https://doi.org/10.1016/j.marchem.2017.12.002, 2018.

Gehlen, M., Beck, L., Calas, G., Flank, A.-M., Van Bennekom, A. J., and Van Beusekom, J. E. E. : Unraveling the atomic structure of biogenic silica: evidence of the structural association of $\mathrm{Al}$ and $\mathrm{Si}$ in diatom frustules, Geochim. Cosmochim. Ac., 66, 16011609, https://doi.org/10.1016/S0016-7037(01)00877-8, 2002.

Gerringa, L. J. A., Slagter, H. A., Bown, J., van Haren, H., Laan, P., De Baar, H. J. W., and Rijkenberg, M. J. A.: Dissolved $\mathrm{Fe}$ and $\mathrm{Fe}$-binding organic ligands in the Mediterranean Sea-GEOTRACES G04, Mar. Chem., 194, 100-113, https://doi.org/10.1016/j.marchem.2017.05.012, 2017.

Gkikas, A., Basart, S., Hatzianastassiou, N., Marinou, E., Amiridis, V., Kazadzis, S., Pey, J., Querol, X., Jorba, O., Gassó, S., and Baldasano, J. M.: Mediterranean intense desert dust outbreaks 
and their vertical structure based on remote sensing data, Atmos. Chem. Phys., 16, 8609-8642, https://doi.org/10.5194/acp16-8609-2016, 2016.

Guieu, C., Desboeufs, K., Albani, S., Alliouane, S., Aumont, O., Barbieux, M., Barrillon, S., Baudoux, A.-C., Berline, L., Bhairy, N., Bigeard, E., Bloss, M., Bressac, M., Brito, J., Carlotti, F., de Liege, G., Dinasquet, J., Djaoudi, K., Doglioli, A., D’Ortenzio, F., Doussin, J.-F., Duforet, L., Dulac, F., Dutay, J.-C., Engel, A., Feliu-Brito, G., Ferre, H., Formenti, P., Fu, F., Garcia, D., Garel, M., Gazeau, F., Giorio, C., Gregori, G., Grisoni, J.-M., Guasco, S., Guittonneau, J., Haëntjens, N., Heimburger, L.-E., Helias, S., Jacquet, S., Laurent, B., Leblond, N., Lefevre, D., Mallet, M., Marañón, E., Nabat, P., Nicosia, A., Obernosterer, I., Perez, L. M., Petrenko, A., Pulido-Villena, E., Raimbault, P., Ridame, C., Riffault, V., Rougier, G., Rousselet, L., Roy-Barman, M., SaizLopez, A., Schmechtig, C., Sellegri, K., Siour, G., Taillandier, V., Tamburini, C., Thyssen, M., Tovar-Sanchez, A., Triquet, S., Uitz, J., Van Wambeke, F., Wagener, T., and Zaencker, B.: BIOGEOCHEMICAL dataset collected during the PEACETIME cruise, SEANOE [data set], https://doi.org/10.17882/75747, 2020.

Guerzoni, S., Chester, R., Dulac, F., Herut, B., Loÿe-Pilot, M. D., Measures, C., Migon, C., Molinaroli, E., Moulin, C., Rossini, P., Saydam, C., Soudine, A., and Ziveri, P.: The role of atmospheric deposition in the biogeochemistry of the Mediterranean Sea, Prog. Oceanogr., 44, 147-190, https://doi.org/10.1016/S00796611(99)00024-5, 1999.

Guieu, C., Loÿe-Pilot, M.D., Ridame, C., and Thomas, C.: Chemical characterization of the Saharan dust end-member; some biological implications for the western Mediterranean, J. Geophys. Res., 107, 4258, https://doi.org/10.1029/2001JD000582, 2002.

Guieu, C., Roy-Barman, M., Leblond, N., Jeandel, C., Souhaut, M., Le Cann, B., Dufour, A., and Bournot, C.: Vertical particle flux in the northeast Atlantic Ocean (POMME experiment), J. Geophys. Res.-Ocean., 110, CO7S18, https://doi.org/10.1029/2004JC002672, 2005.

Guieu, C., Aumont, O., Paytan, A., Bopp, L., Law, C. S., Mahowald, N., Achterberg, E. P., Marañón, E., Salihoglu, B., Crise, A., Wagener, T., Herut, B., Desboeufs, K., Kanakidou, M., Olgun, N., Peters, F., Pulido-Villena, E., Tovar-Sanchez, A., and Völker, C.: The significance of episodicity in atmospheric deposition to Low Nutrient Low Chlorophyll regions, Global Biogeochem. Cy., 28, 1179-1198, https://doi.org/10.1002/2014GB004852, 2014a.

Guieu, C., Ridame, C., Pulido-Villena, E., Bressac, M., Desboeufs, K., and Dulac, F.: Impact of dust deposition on carbon budget: a tentative assessment from a mesocosm approach, Biogeosciences, 11, 5621-5635, https://doi.org/10.5194/bg-115621-2014, 2014b.

Guieu, C., D’Ortenzio, F., Dulac, F., Taillandier, V., Doglioli, A., Petrenko, A., Barrillon, S., Mallet, M., Nabat, P., and Desboeufs, K.: Introduction: Process studies at the air-sea interface after atmospheric deposition in the Mediterranean Seaobjectives and strategy of the PEACETIME oceanographic campaign (May-June 2017), Biogeosciences, 17, 5563-5585, https://doi.org/10.5194/bg-17-5563-2020, 2020.

Hamm, C. E.: Interactive aggregation and sedimentation of diatoms and clay-sized lithogenic material, Limnol. Oceanogr., 47, 17901795, https://doi.org/10.4319/lo.2002.47.6.1790, 2002.

Han, Q., Moore, J. K., Zender, C., Measures, C., and Hydes, D.: Constraining oceanic dust deposition using sur- face ocean dissolved Al, Global Biogeochem. Cy., 22, 2, https://doi.org/10.1029/2007GB002975, 2008.

Han, Q., Zender, C., Moore, J. K., Buck, C. S., Chen, Y., Johansen, A., and Measures, C.: Global estimates of mineral dust aerosol iron and aluminum solubility that account for particle size using diffusion-controlled and surface-area controlled approximations, Global Biogeochem. Cy., 26, GB2038, https://doi.org/10.1029/2011GB004186, 2012.

Han, J., Wang, W., Kwon, Y. C., Hong, S. Y., Tallapragada, V., and Yang, F.: Updates in the NCEP GFS cumulus convection schemes with scale and aerosol awareness, Weather Forecast., 32, 2005-2017, https://doi.org/10.1175/WAF-D-170046.1, 2017.

Heimbürger, L. E., Migon, C., and Cossa, D.: Impact of atmospheric deposition of anthropogenic and natural trace metals on Northwestern Mediterranean surface waters: A box model assessment, Environ. Pollut., 159, 1629-1634, https://doi.org/10.1016/j.envpol.2011.02.046, 2011.

Herut, B., Rahav, E., Tsagaraki, T. M., Giannakourou, A., Tsiola, A., Psarra, S., Lagaria, A., Papageorgiou, N., Mihalopoulos, N., Theodosi, C. N., Violaki, K., Stathopoulou, E., Scoullos, M., Krom, M. D., Stockdale, A., Shi, Z., Berman-Frank, I., Meador, T. B., Tanaka, T., and Paraskevi, P.: The potential impact of Saharan dust and polluted aerosols on microbial populations in the East Mediterranean Sea, an overview of a mesocosm experimental approach, Front. Mar. Sci., 3, p. 226, https://doi.org/10.3389/fmars.2016.00226, 2016.

Huffman, G. J., Bolvin, D. T., Nelkin, E. J., and Tan, J.: Integrated Multi-satellitE Retrievals for GPM (IMERG) technical documentation, NASA/GSFC Code, 612, 2015.

Huneeus, N., Basart, S., Fiedler, S., Morcrette, J.-J., Benedetti, A., Mulcahy, J., Terradellas, E., Pérez García-Pando, C., Pejanovic, G., Nickovic, S., Arsenovic, P., Schulz, M., Cuevas, E., Baldasano, J. M., Pey, J., Remy, S., and Cvetkovic, B.: Forecasting the northern African dust outbreak towards Europe in April 2011: a model intercomparison, Atmos. Chem. Phys., 16, 4967-4986, https://doi.org/10.5194/acp-16-4967-2016, 2016.

Hydes, D. and Liss, P.: Fluorimetric method for the determination of low concentrations of dissolved aluminium in natural waters, Analyst, 101, 922-931, https://doi.org/10.1039/AN9760100922, 1976.

Jacquet, S. H. M., Dehairs, F., Lefèvre, D., Cavagna, A. J., Planchon, F., Christaki, U., Monin, L., André, L., Closset, I., and Cardinal D.: Early Spring Mesopelagic Carbon Remineralization and Transfer Efficiency in the Naturally IronFertilized Kerguelen Area, Biogeosciences, 12, 1713-1731, https://doi.org/10.5194/bg-12-1713-375, 2015.

Jacquet, S. H. M., Tamburini, C., Garel, M., Dufour, A., Van Vambeke, F., Le Moigne, F. A. C., Bhairy, N., and Guasco, S.: Particulate biogenic barium tracer of mesopelagic carbon remineralization in the Mediterranean Sea (PEACETIME project), Biogeosciences, 18, 5891-5902, https://doi.org/10.5194/bg-185891-2021, 2021.

Jickells, T. D., An, Z. S., Andersen, K. K., Baker, A. R., Bergametti, G., Brooks, N., Cao, J. J., Boyd, P. W., Duce, R. A., Hunter, K. A., Kawahata, H., Kubilay, N., laRoche, J., Liss, P. S., Mahowald, N., Prospero, J. M., Ridgwell, A. J., Tegen, I., and Torres, R.: Global iron connections between desert 
dust, ocean biogeochemistry, and climate, Science, 308, 67-71, https://doi.org/10.1126/science.1105959, 2005.

Kishcha P., Nickovic S., Ganor E., Kordova L., and Alpert P.: Saharan Dust over the Eastern Mediterranean: Model Sensitivity, in: Air Pollution Modeling and Its Application XIX, edited by: Borrego, C. and Miranda, A. I., NATO Science for Peace and Security Series Series C: Environmental Security, Springer, Dordrecht, https://doi.org/10.1007/978-1-4020-8453-9_39, 2008.

Koning, E., Gehlen, M., Flank, A.-M., Calas, G., and Epping, E.: Rapid post-mortem incorporation of aluminum in diatom frustules: evidence from chemical and structural analyses, Mar. Chem., 106, 208-222, https://doi.org/10.1016/j.marchem.2006.06.009, 2007.

Kubilay, N., Nickovic, S., Moulin, C., and Dulac, F.: An illustration of the transport and deposition of mineral dust onto the eastern Mediterranean, Atmos. Environ., 34, 1293-1303, https://doi.org/10.1016/S1352-2310(99)00179-X, 2000.

Laurenceau-Cornec, Le Moigne, F. A. C., Gallinari, M., Moriceau, B., Toullec, J., Iversen, M. H., Engel, A., and De La Rocha, C. L.: New guidelines for the application of Stokes' models to the sinking velocity of marine aggregates, Limnol. Oceanogr., 65, 1264-1285, https://doi.org/10.1002/lno.11388, 2020.

Li, F., Ren, J., Yan, L., Liu, S., Liu, C., Zhou, F., and Zhang, J.: The biogeochemical behavior of dissolved aluminum in the southern Yellow Sea: Influence of the spring phytoplankton bloom, Chin. Sci. Bull., 58, 238-248, https://doi.org/10.1007/s11434012-5512-5, 2013.

Liu, Q., Zhou, L., Liu, F., Fortin, C., Tan, Y., Huang, L., and Campbell, P. G.: Uptake and subcellular distribution of aluminum in a marine diatom, Ecotox. Environ. Safe., 169, 85-92, https://doi.org/10.1016/j.ecoenv.2018.10.095, 2019.

Loucaides, S., Michalopoulos, P., Presti, M., Koning, E., Behrends, T., and Van Cappellen, P.: Seawater-mediated interactions between diatomaceous silica and terrigenous sediments: results from long-term incubation experiments, Chem. Geol., 270, 6879, https://doi.org/10.1016/j.chemgeo.2009.11.006, 2010.

Loÿe-Pilot, M.-D. and Martin, J.-M.: Saharan dust input to the western Mediterranean: an eleven years record in Corsica, in: The Impact of Desert Dust Across the Mediterranean, edited by: Guerzoni, S. and Chester, R., Environmental Science and Technology Library, Springer, Dordrecht, 11, 191-199, https://doi.org/10.1007/978-94-017-3354-0_18, 1996.

Mackenzie, F. T., Stoffyn, M., and Wollast, R.: Aluminum in seawater: control by biological activity, Science, 199, 680-682, https://doi.org/10.1126/science.199.4329.680, 1978.

Marañón, E., Van Wambeke, F., Uitz, J., Boss, E. S., Dimier, C., Dinasquet, J., Engel, A., Haëntjens, N., Pérez-Lorenzo, M., Taillandier, V., and Zäncker, B.: Deep maxima of phytoplankton biomass, primary production and bacterial production in the Mediterranean Sea, Biogeosciences, 18, 1749-1767, https://doi.org/10.5194/bg-18-1749-2021, 2021.

Measures, C. I. and Brown, E. T.: Estimating Dust Input to the Atlantic Ocean Using Surface Water Aluminium Concentrations, in: The Impact of Desert Dust Across the Mediterranean, edited by: Guerzoni, S. and Chester, R., Environmental Science and Technology Library, Springer, Dordrecht, 11, 301-311, https://doi.org/10.1007/978-94-017-3354-0_30, 1996.

Measures, C. I., Landing, W. M., Brown, M. T., and Buck, C. S.: High-resolution $\mathrm{Al}$ and $\mathrm{Fe}$ data from the At- lantic Ocean CLIVAR-CO 2 repeat hydrography A16N transect: extensive linkages between atmospheric dust and upper ocean geochemistry, Global Biogeochem. Cy., 22, GB1005, https://doi.org/10.1029/2007GB003042, 2008.

Measures, C., Sato, T., Vink, S., Howell, S., and Li, Y.: The fractional solubility of aluminium from mineral aerosols collected in Hawaii and implications for atmospheric deposition of biogeochemically important trace elements, Mar. Chem., 120, 144-153, https://doi.org/10.1016/j.marchem.2009.01.014, 2010.

Menzel Barraqueta, J. L., Klar, J. K., Gledhill, M., Schlosser, C., Shelley, R., Planquette, H. F., Wenzel, B., Sarthou, G., and Achterberg, E. P.: Atmospheric deposition fluxes over the Atlantic Ocean: a GEOTRACES case study, Biogeosciences, 16, 1525-1542, https://doi.org/10.5194/bg-16-1525-2019, 2019.

Meskhidze, N., Völker, C., Al-Abadleh, H. A., Barbeau, K., Bressac, M., Buck, C., Bundy, R. M., Croot, P., Feng, Y., Ito, A. Johansen, A. M., Landing, W. M., Mao, J., Myriokefalitakis, S., Ohnemus, D., Pasquier, B., and Ye, Y.: Perspective on identifying and characterizing the processes controlling iron speciation and residence time at the atmosphere-ocean interface, Mar. Chem., 217, 103704, https://doi.org/10.1016/j.marchem.2019.103704, 2019.

Middag, R., van Hulten, M. M. P., van Aken, H. M., Rijkenberg, M. J. A., Gerringa, L. J. A., Laan, P., and de Baar, H. J. W.: Dissolved aluminium in the ocean conveyor of the West Atlantic Ocean: mirror image of the biological cycle?, Mar. Chem., 177, 69-86, https://doi.org/10.1016/j.marchem.2015.02.015, 2015.

Migon, C., Sandroni, V., Marty, J. C., Gasser, B., and Miquel, J. C.: Transfer of atmospheric matter through the euphotic layer in the northwestern Mediterranean: seasonal pattern and driving forces, Deep-Sea Res. Pt. II, 49, 2125-2141, https://doi.org/10.1016/S0967-0645(02)00031-0, 2002.

Misic, C., Castellano, M., Ruggieri, N., and Harriague, A. C.: Variations in ectoenzymatic hydrolytic activity in an oligotrophic environment (Southern Tyrrhenian Sea, W Mediterranean), J. Mar. Syst., 73, 123-137, https://doi.org/10.1016/j.jmarsys.2007.10.003, 2008.

Moore, C. M., Mills, M., Arrigo, K., Berman-Frank, I., Bopp, L., Boyd, P. W., Galbraith, E. D., Geider, R. J., Guieu, C., Jaccard, S. L., Jickells, T. D., La Roche, J., Lenton, T. M., Mahowald, N. M., Marañón, E., Marinov, I., Moore, J. K., Nakatsuka, T.,Oschlies, A., Saito, M. A., Thingstad, T. F., Tsuda, A., and Ulloa, O.: Processes and patterns of oceanic nutrient limitation, Nat. Geosci., 6, 701-710, https://doi.org/10.1038/ngeo1765, 2013.

Moran, S. B. and Moore, R. M.: Temporal variations in dissolved and particulate aluminium during a spring bloom, Estuar. Coast. Shelf Sci., 27, 205-215, https://doi.org/10.1016/02727714(88)90090-X,1988a.

Moran, S. B. and Moore, R. M.: Evidence from mesocosm studies for biological removal of dissolved aluminium from sea water, Nature, 335, 706-708, https://doi.org/10.1038/335706a0, 1988b.

Mullin, J. and Riley, J. P.: The colorimetric determination of silicate with special reference to sea and natural waters, Anal. Chim. Ac., 12, 162-176, https://doi.org/10.1016/S0003-2670(00)87825-3, 1955.

Nelson, D. M., Smith Jr, W. O., Muench, R. D., Gordon, L. I., Sullivan, C. W., and Husby, D. M.: Particulate matter and nutrient distributions in the ice-edge zone of the Weddell Sea: relation- 
ship to hydrography during late summer, Deep-Sea Res. Pt. I, 36, 191-209, https://doi.org/10.1016/0198-0149(89)90133-7, 1989.

Nowald, N., Iversen, M. H., Fischer, G., Ratmeyer, V., and Wefer, G.: Time series of in-situ particle properties and sediment trap fluxes in the coastal upwelling filament off Cape Blanc, Mauritania, Progr. Oceanogr. Pt. A, 137, 1-11, https://doi.org/10.1016/j.pocean.2014.12.015, 2015.

Orians, K. J. and Bruland, K. W.: The biogeochemistry of aluminum in the Pacific Ocean, Earth Planet. Sc. Lett., 78, 397-410, https://doi.org/10.1016/0012-821X(86)90006-3, 1986.

Planquette, H. and Sherrell, R. M.: Sampling for particulate trace element determination using water sampling bottles: methodology and comparison to in situ pumps, Limnol. Oceanogr.-Method., 10, 367-388, https://doi.org/10.4319/lom.2012.10.367, 2012.

Quétel, C. R., Remoudaki, E., Davies, J. E., Miquel, J. C., Fowler, S. W., Lambert, C. E., Bergametti, G., and Buat-Ménard, P.: Impact of atmospheric deposition on particulate iron flux and distribution in northwestern Mediterranean waters, Deep-Sea Res. Pt. I, 40, 989-1002, https://doi.org/10.1016/0967-0637(93)90085H, 1993.

Rijkenberg, M., Powell, C., Dall'Osto, M., Nielsdottir, M., Patey, M., Hill, P., Baker, A., Jickells, T., Harrison, R., and Achterberg, E.: Changes in iron speciation following a Saharan dust event in the tropical North Atlantic Ocean, Mar. Chem., 110, 56-67, https://doi.org/10.1016/j.marchem.2008.02.006, 2008.

Rolison, J. M., Middag, R., Stirling, C. H., Rijkenberg, M. J. A., and De Baar, H. J. W.: Zonal distribution of dissolved aluminium in the Mediterranean Sea, Mar. Chem., 177, 87-100, https://doi.org/10.1016/j.marchem.2015.05.001, 2015.

Sarrand, B., Dulac, F., Baldi, M., Bargaoui, Z., Cindrić, K., Ducrocq, V., Labiadh, M., Schiavone, J., de Silvestri, L., Somot, S., and Tovar-Sánchez, A.: Precipitation in the Mediterranean basin as seen from the 2000-2010 TRMM-3B42-v6 database, EGU General Assembly Conference Abstracts, Viena, Austria, 22-27 April 2012, 11965, 2012.

Sarthou, G. and Jeandel, C.: Seasonal variations of iron concentrations in the Ligurian Sea and iron budget in the Western Mediterranean Sea, Mar. Chem., 74, 115-129, https://doi.org/10.1016/S0304-4203(00)00119-5, 2001.

Schallenberg, C., Ross, A. R., Davidson, A. B., Stewart, G. M., and Cullen, J. T.: Temporal variability of dissolved iron species in the mesopelagic zone at Ocean Station PAPA, J. Mar. Syst., 172, 128-136, https://doi.org/10.1016/j.jmarsys.2017.03.006, 2017.

Shelley, R. U., Landing, W. M., Ussher, S. J., Planquette, H., and Sarthou, G.: Regional trends in the fractional solubility of Fe and other metals from North Atlantic aerosols (GEOTRACES cruises GA01 and GA03) following a two-stage leach, Biogeosciences, 15, 2271-2288, https://doi.org/10.5194/bg-15-2271-2018, 2018.

Spokes, L. J., Jickells, T. D., and Lim, B.: Solubilisation of aerosol trace metals by cloud processing: A laboratory study, Geochim. Cosmochim. Ac., 58, 3281-3287, https://doi.org/10.1016/00167037(94)90056-6, 1994.

Spyrou, C., Mitsakou, C., Kallos, G., Louka, P., and Vlastou, G.: An improved limited area model for describing the dust cycle in the atmosphere, J. Geophys. Res., 115, D17211, https://doi.org/10.1029/2009JD013682, 2010

Tagliabue, A., Sallée, J. B., Bowie, A. R., Lévy, M., Swart, S., and Boyd, P. W.: Surface-water iron supplies in the Southern
Ocean sustained by deep winter mixing, Nat. Geosci., 7, 314320, https://doi.org/10.1038/ngeo2101, 2014.

Tagliabue, A., Aumont, O., DeAth, R., Dunne, J. P., Dutkiewicz, S., Galbraith, E., Misumi, K., Moore, J. K., Ridgwell, A., Sherman, E., Stock, C., Vichi, M., Völker, C., and Yool, A.: How well do global ocean biogeochemistry models simulate dissolved iron distributions?, Global Biogeochem. Cy., 30, 149174, https://doi.org/10.1002/2015GB005289, 2016.

Tagliabue, A., Bowie, A. R., Boyd, P. W., Buck, K. N., Johnson, K. S., and Saito, M. A.: The integral role of iron in ocean biogeochemistry, Nature, 543, 51-59, https://doi.org/10.1038/nature21058, 2017.

Taillandier, V., Prieur, L., d'Ortenzio, F., Ribera d'Alcalà, M., and Pulido-Villena, E.: Profiling float observation of thermohaline staircases in the western Mediterranean Sea and impact on nutrient fluxes, Biogeosciences, 17, 3343-3366, https://doi.org/10.5194/bg-17-3343-2020, 2020.

Ternon, E., Guieu, C., Loÿe-Pilot, M.-D., Leblond, N., Bosc, E., Gasser, B., Miquel, J.-C., and Martín, J.: The impact of Saharan dust on the particulate export in the water column of the North Western Mediterranean Sea, Biogeosciences, 7, 809-826, https://doi.org/10.5194/bg-7-809-2010, 2010.

Thieuleux, F., Moulin, C., Bréon, F. M., Maignan, F., Poitou, J., and Tanré, D.: Remote sensing of aerosols over the oceans using MSG/SEVIRI imagery, Ann. Geophys., 23, 3561-3568, https://doi.org/10.5194/angeo-23-3561-2005, 2005.

Tovar-Sánchez, A., Rodríguez-Romero, A., Engel, A., Zäncker, B., Fu, F., Marañón, E., Pérez-Lorenzo, M., Bressac, M., Wagener, T., Triquet, S., Siour, G., Desboeufs, K., and Guieu, C.: Characterizing the surface microlayer in the Mediterranean Sea: trace metal concentrations and microbial plankton abundance, Biogeosciences, 17, 2349-2364, https://doi.org/10.5194/bg-172349-2020, 2020.

Twining, B. S., Rauschenberg, S., Morton, P. L., Ohnemus, D. C., and Lam, P. J.: Comparison of particulate trace element concentrations in the North Atlantic Ocean as determined with discrete bottle sampling and in situ pumping, Deep-Sea Res. Pt. II, 116, 273-282, https://doi.org/10.1016/j.dsr2.2014.11.005, 2015a.

Twining, B. S., Rauschenberg, S., Morton, P. L., and Vogt, S.: Metal contents of phytoplankton and labile particulate material in the North Atlantic Ocean, Progr. Oceanogr., 137, 261-283, https://doi.org/10.1016/j.pocean.2015.07.001, 2015b.

Van Bennekom A. J., Jansen F., Van Der Gaast S., Van Iperen J., and Pieters J.: Aluminum-rich opal: An intermediate in the preservation of biogenic silica in the Zaire (Congo) deep-sea fan, Deep-Sea Res., 36, 173-190, https://doi.org/10.1016/01980149(89)90132-5, 1989.

van der Jagt, H., Friese, C., Stuut, J. B. W., Fischer, G., and Iversen, M. H.: The ballasting effect of Saharan dust deposition on aggregate dynamics and carbon export: Aggregation, settling, and scavenging potential of marine snow, Limnol. Oceanogr., 63, 1386-1394, https://doi.org/10.1002/lno.10779, 2018.

Van Wambeke, F., Taillandier, V., Deboeufs, K., Pulido-Villena, E., Dinasquet, J., Engel, A., Marañón, E., Ridame, C., and Guieu, C.: Influence of atmospheric deposition on biogeochemical cycles in an oligotrophic ocean system, Biogeosciences, 18, 5699-5717, https://doi.org/10.5194/bg-18-5699-2021, 2021.

Velasquez, I. B., Ibisanmi, E., Maas, E. W., Boyd, P. W., Nodder, S., and Sander, S. G.: Ferrioxamine siderophores de- 
tected amongst iron binding ligands produced during the remineralization of marine particles, Front. Mar. Sci., 3, p. 172, https://doi.org/10.3389/fmars.2016.00172, 2016.

Vincent, J., Laurent, B., Losno, R., Bon Nguyen, E., Roullet, P., Sauvage, S., Chevaillier, S., Coddeville, P., Ouboulmane, N., di Sarra, A. G., Tovar-Sánchez, A., Sferlazzo, D., Massanet, A., Triquet, S., Morales Baquero, R., Fornier, M., Coursier, C., Desboeufs, K., Dulac, F., and Bergametti, G.: Variability of mineral dust deposition in the western Mediterranean basin and south-east of France, Atmos. Chem. Phys., 16, 8749-8766, https://doi.org/10.5194/acp-16-8749-2016, 2016.

Wagener, T., Pulido-Villena, E., and Guieu, C.: Dust iron dissolution in seawater: Results from a one-year time-series in the Mediterranean Sea, Geophys. Res. Lett., 35, L16601, https://doi.org/10.1029/2008GL034581, 2008.

Wagener, T., Guieu, C., and Leblond, N.: Effects of dust deposition on iron cycle in the surface Mediterranean Sea: results from a mesocosm seeding experiment, Biogeosciences, 7, 3769-3781, https://doi.org/10.5194/bg-7-3769-2010, 2010.
Whitby, H., Bressac, M., Sarthou, G., Ellwood, M. J., Guieu, C., and Boyd, P. W.: Contribution of electroactive humic substances to the iron-binding ligands released during microbial remineralization of sinking particles, Geophys. Res. Lett., 47, e2019GL086685, https://doi.org/10.1029/2019GL086685, 2020.

Wuttig, K., Wagener, T., Bressac, M., Dammshäuser, A., Streu, P., Guieu, C., and Croot, P. L.: Impacts of dust deposition on dissolved trace metal concentrations ( $\mathrm{Mn}, \mathrm{Al}$ and $\mathrm{Fe}$ ) during a mesocosm experiment, Biogeosciences, 10, 2583-2600, https://doi.org/10.5194/bg-10-2583-2013, 2013.

Ye, Y., Wagener, T., Völker, C., Guieu, C., and Wolf-Gladrow, D. A.: Dust deposition: iron source or sink? A case study, Biogeosciences, 8, 2107-2124, https://doi.org/10.5194/bg-8-21072011, 2011. 